\title{
Applied Research of the Hygrothermal Behaviour of an Internally Insulated Historic Wall without Vapour Barrier: In Situ Measurements and Dynamic Simulations
}

\author{
Mirco Andreotti ${ }^{1}$, Dario Bottino-Leone ${ }^{2}$, Marta Calzolari ${ }^{3}$, Pietromaria Davoli ${ }^{4}(\mathbb{D}$, \\ Luisa Dias Pereira ${ }^{4, * \mathbb{D}}$, Elena Lucchi ${ }^{2}$ and Alexandra Troi ${ }^{2}$ \\ 1 Istituto Nazionale di Fisica Nucleare, Sezione di Ferrara, 44122 Ferrara, Italy; mirco.andreotti@fe.infn.it \\ 2 Eurac Research, Institute for Renewable Energy, 39100 Bolzano, Italy; dario.bottino@eurac.edu (D.B.-L.); \\ elena.lucchi@eurac.edu (E.L.); alexandra.troi@eurac.edu (A.T.) \\ 3 Department of Engineering and Architecture, University of Parma, 43124 Parma, Italy; \\ marta.calzolari@unipr.it \\ 4 Architettura Energia Research Centre, Department of Architecture, University of Ferrara, 44121 Ferrara, Italy; \\ pietromaria.davoli@unife.it \\ * Correspondence: dsplmr@unife.it; Tel.: +39-0532-293631
}

Received: 12 May 2020; Accepted: 17 June 2020; Published: 1 July 2020

check for updates

\begin{abstract}
The hygrothermal behaviour of an internally insulated historic wall is still hard to predict, mainly because the physical characteristics of the materials composing the historic wall are unknown. In this study, the hygrothermal assessment of an internally thermal insulated masonry wall of an historic palace located in Ferrara, in Italy, is shown. In situ non-destructive monitoring method is combined with a hygrothermal simulation tool, aiming to better analyse and discuss future refurbishment scenarios. In this context, the original U-value of the wall (not refurbished) is decreased from $1.44 \mathrm{~W} / \mathrm{m}^{2} \mathrm{~K}$ to $0.26 \mathrm{~W} / \mathrm{m}^{2} \mathrm{~K}(10 \mathrm{~cm}$ stone wool). Under the site specific conditions of this wall, not reached by the sun or rain, it was verified that even in the absence of vapour barrier, no frost damage is likely to occur and the condensation risk is very limited. Authors proposed further discussion based on simulation. The results showed that the introduction of a second gypsum board to the studied technology compensated such absence, while the reduction of the insulation material thickness provides a reduction of RH peaks in the interstitial area by $1 \%$; this second solution proved to be more efficient, providing a 3\% RH reduction and the avoidance of further thermal losses.
\end{abstract}

Keywords: HeLLo; energy retrofit; non-destructive test; in situ; hygrothermal measurement; dynamic conditions; hygrothermal simulation; historic wall

\section{Introduction}

One of the most efficient ways to promote historic buildings (HB) sustainability is keeping them in use. Contributing to the life extent of $\mathrm{HB}$, even those of heritage value, necessarily requires conservation improvements. In other words, safeguarding cultural heritage for future generations means trying to support the quality implementation of energy efficiency measures, needed to mitigate climate change [1] and to keep the buildings used. This means that, at this moment, the conservation aspect of $\mathrm{HB}$ can no longer be dissociated from its energy refurbishment. Nonetheless, the adaptation to such changes, e.g., adaptive re-use [2], retrofitting [3] and/or energy efficiency improvements actions [4], can also bring some risks. These risks are particularly likely to occur when dealing with thermal insulation of $\mathrm{HB}$ with patrimonial or heritage value. Here, adding interior thermal insulation 
layers to a façade is often the solely option, because the external insulation is frequently not suitable for preserving its aesthetical and cultural values. This action inevitably introduces changes to the hygrothermal behaviour (temperature and moisture conditions) of the historic walls, which can lead to interstitial condensation, frost damage or mould growth [5]. In other situations, the presence of water in different forms can also cause the reduction of the thermal performance of sub-components of HB's envelope, as pointed in [6]. Furthermore, they may lead to structural deterioration, saline efflorescence, or aesthetical decay.

Until a few years ago, most research on energy retrofit strategies and guidelines (materials, installation typologies $[7,8])$, focused on software simulations [9] and lab tests ([10,11]). Only recently have in situ measurements started to be performed. This delay is due to several aspects, for example: (i) long time and high costs of the research [12]; (ii) intrinsic uncertainties of implementation of the field campaigns; (iii) required invasive methods not compatible with HB protection guidelines; and (iv) field limitations because the results are often specific to each case-study. Despite these aspects, as pointed in [13] (p. 367) as future research directions, "in situ methods in historical buildings" are emerging and starting to take further steps towards the complex hygrothermal analysis of the internal insulation of $\mathrm{HB}$ as retrofit actions.

Many of these studies rose from the experience of European projects, such as: 3ENCULT [14], Co2olBricks [15], EFFESUS, [16]. The 3ENCULT project, which aimed "to bridge the gap between cultural heritage and climate protection, ( . . ) communicating productively to find the right solution for a particular building" [17] (p. 10), contributed to the development of capillary active materials for the internal insulation. In [18], an output of the Co2olBricksproject, some of the problems concerning internal thermal insulation are addressed, alike moisture in brick wall construction. Authors tested five insulation materials and proposed an optimal selection, using the TOPSIS method with grey numbers. The EFFESUS project developed and tested two innovative insulation materials for the internal insulation of HB (blown-in aerogel blanket and insulating mortar), balancing their thermal performance and heritage conservation, in terms of reversibility, aesthetical impact, and material compatibility $[19,20]$.

Several studies verified a significant knowledge gap between the measured thermal performance and the simulated behaviour, especially for historic walls $([21,22])$, as in many situations, the wall composition is unknown [23], and the estimations are grounded on assumptions [24]. Hygrothermal simulation, more recently implemented, has also been contributing to bridge that gap [25]. Nonetheless, wrong estimations or excessive simplifications may have a severe impact on their thermal behaviour assessment, as well as on retrofit interventions [9]. Thus, field studies become mandatory to find the most suitable internal insulation solution, with regards to both the thermal and hygrothermal performance of HB. Many of these studies focus solely on the thermal performance of the walls, as the work developed by Bienvenido-Huertas et al. on the improvement of in-situ assessment of thermal transmittance (U-value) of historic walls [26], or the study of [27] on the energy efficiency proposal of a historical building in Naples, still neglect the undesirable effect that the presence of moisture in the wall structure might have. As pointed out in [28] (p. 117), "temperature and moisture conditions strongly influence thermal conductance of some materials", besides, it is also recognized that "condensed water increases the effective thermal conductivity of building materials" [29] (p. 1674).

In [30], Litti et al. gave a step forward proposing an indirect non-invasive monitoring procedure for the onsite evaluation of the thermal performance of traditional buildings' masonries, also quantifying the alteration due to the moisture distribution variation. More recently, the hygrothermal complexity of this matter has been fully embraced. In [31], authors studied the hygrothermal performance of four thermal insulation materials for an internally insulated brick wall in a cold climate. In [32], in its turn, in a deep study conducted in Denmark, authors presented long term in situ measurements of four cases (from 1877-1932) of internally insulated historic solid masonry walls, monitored at critical points, also creating numerical models which were validated against measurements. In this case, two different insulation systems with different insulation thicknesses were studied [32]. 
In this context, the paper presents part of the results of the HeLLo project-Heritage Energy Living Lab Onsite [33], which addresses one of the most relevant problems of HB energy refurbishment: the hygrothermal behaviour of internally insulated historic walls. In this project, to analyse this issue, in situ monitoring campaigns were performed. This study aims to assess thermal insulation technologies (including insulation material and installation system), among the most widespread in the market and used by professionals for new or existing buildings, to verify the hygrothermal behaviour when applied to HB. The final goal is to enhance the awareness of all the actors involved in the energy performance improvement of the HB envelope (designers, owners, heritage authority's members, and companies), for a conscious management of the entire process.

Within the paper, one of the studied thermal insulation technologies is deeply analysed. Initially, the case study is presented along with the methodology followed to develop the research (Section 2). In Section 3, the monitoring campaign is unveiled, along with the data acquisition system. Data collection was then used to validate 2D hygrothermal simulations performed in Delphin 6.0.20 ${ }^{\circledR}$ (Section 4) [34], further discussed in Section 5. All these steps have thoroughly contributed to enrich the knowledge and safety levels of internal insulation of a historic brick wall, regarding the moisture performance, of which the main conclusions are shown in Section 6.

\section{Case Study and Methods}

\subsection{Case Study Presentation}

A real in situ laboratory was settled to assess and analyse the hygrothermal performance of different insulation thermal technologies applied to historic masonry walls [33]. The in situ experiment (as in [32]) was established in a historic palace located in Ferrara (Italy): Palazzo Tassoni Estense, a 15th century listed building part of an UNESCO site [35] (UNESCO-United Nations Educational, Scientific and Cultural Organization). This palace has been the subject of several studies, some of which have led to an architecture intervention of restoration [36].

The room selected to perform the study is located on the ground floor of a not-yet refurbished and naturally ventilated part of the palace (Figure 1). Due to the reminiscences of highly probable presence of two chimneys on two of the outer walls of this room (Figure 2), it was decided to undertake the study on the remaining wall, NE oriented, under a porch (Figure 3). "Though this situation does not correspond to a 'worst-case scenario'" [37] (p. 2), authors recognize the limitation of their study. The results obtained are limited to this experiment condition: "rainwater might not reach directly the wall, but neither does the sun, i.e., both the capacities of wetting/absorbing and drying are limited" [37] (p. 2).

As this room is $700 \mathrm{~m}^{3}$, aiming to minimize energy consumption and the impacts on the historic room, two in situ metering hot boxes adapted for $\mathrm{HB}$ were constructed, aiming to improve the overall experiment sustainability [38], i.e., two small rooms with controlled indoor hygrothermal conditions were created, inside a big, unoccupied and environmentally uncontrolled room.

Besides the two boxes construction, settled to assure a temperature difference $(\Delta T)$, between indoor and outdoor environment, the thermal insulation technologies were also installed according to the best practices; all of them were installed by technicians of the construction sector appointed directly by the companies (see also Section 2.2 for further details).

\subsection{Technical Worktable and Selection of the Insulation Technologies}

As part of the actions of the HeLLo project, a technical worktable with the national conservation authorities and material's companies was established [39], in order to assess the most suitable technological solutions to balance the needs of all the actors involved in the action: scientific aims, conservation aspects and building market's best practices. As previously outlined, the goal of the research is to test some insulation technologies, commonly widespread in the market for new or recent 
buildings, but suitable to be used in HB. All pros and cons for the energy retrofit have been considered and discussed. Three main criteria are considered, according to [40]:

- Conservation aspects, referred to the elements to preserve (i.e., decorations, finishing), to the aesthetical aspect of the finishing (e.g., proportions, materials, colours, textures), and to the reversibility (i.e., fastening system, and assembly and installation method);

- Energy efficiency referred to the final thickness, laying of the materials and U-value which justify the intervention-balance between thermal performance improvement and conservation aspects);

- Hygrothermal aspects, referred to the use of the vapour barrier. One of the innovative aspects of the HeLLo project is to verify the use of common insulation technologies without vapour barrier, differently from market suggestions for intervention in existing or new buildings, just to "stress" the performance of the tested stratigraphy and to keep the original vapour transport (i.e., low vapour resistance or vapour open materials), typical of HB materials [41]. This option enables summer drying potential of the historic envelope or the potential existing humidity in the wall (e.g., rising damp).
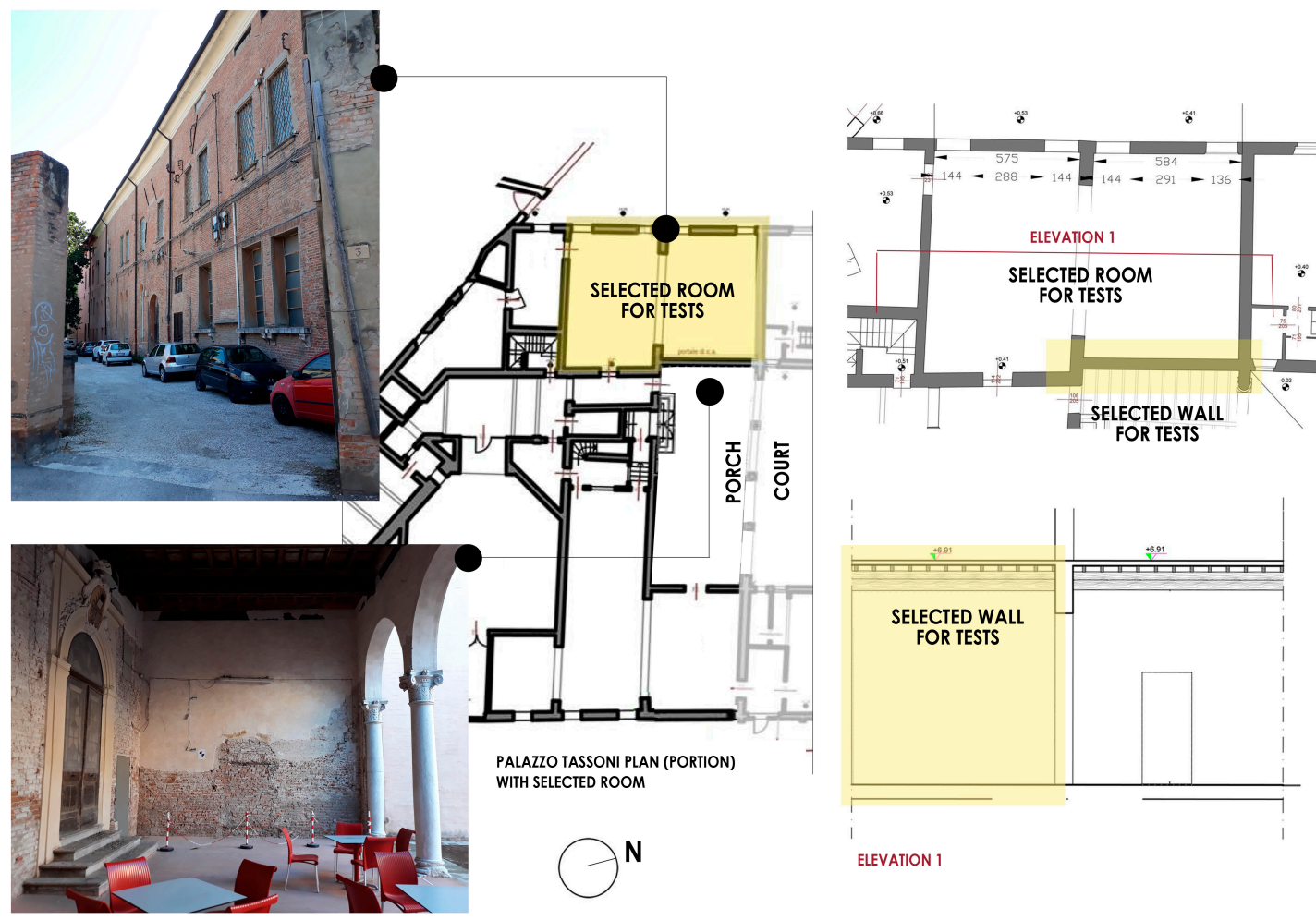

Figure 1. Palazzo Tassoni Estense: ground floor plan with the identification of the room where the experiment is carried out. Views of the external walls of the selected room: the one on the top left represents the front view from via Cammello, the one on the bottom left is a view of the wall under the porch (selected to be studied). The yellow shape underlines the selected room and the corresponding wall selected for the tests. 

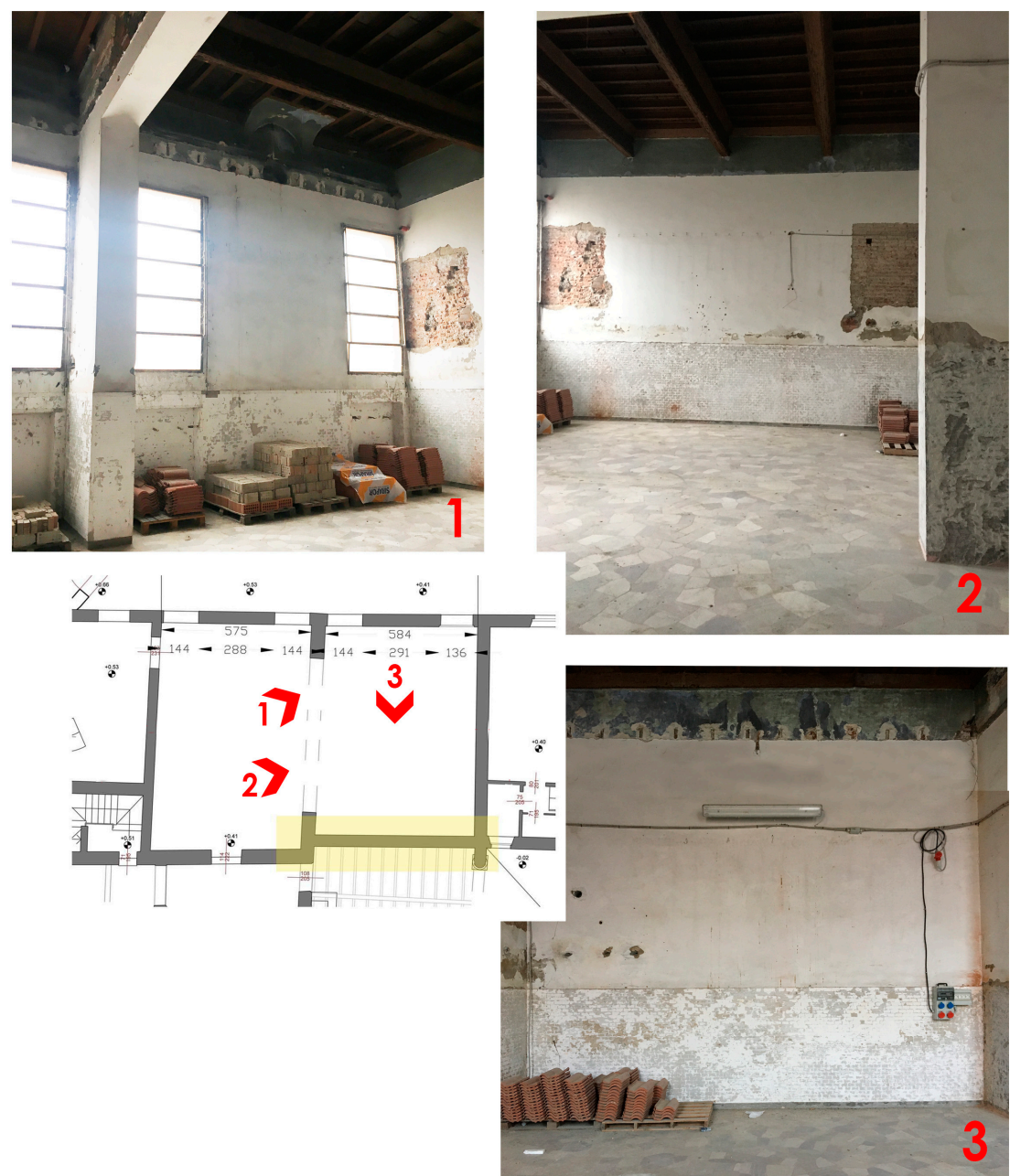

Figure 2. Internal views of the room. The picture 3 represents the wall selected for the tests.

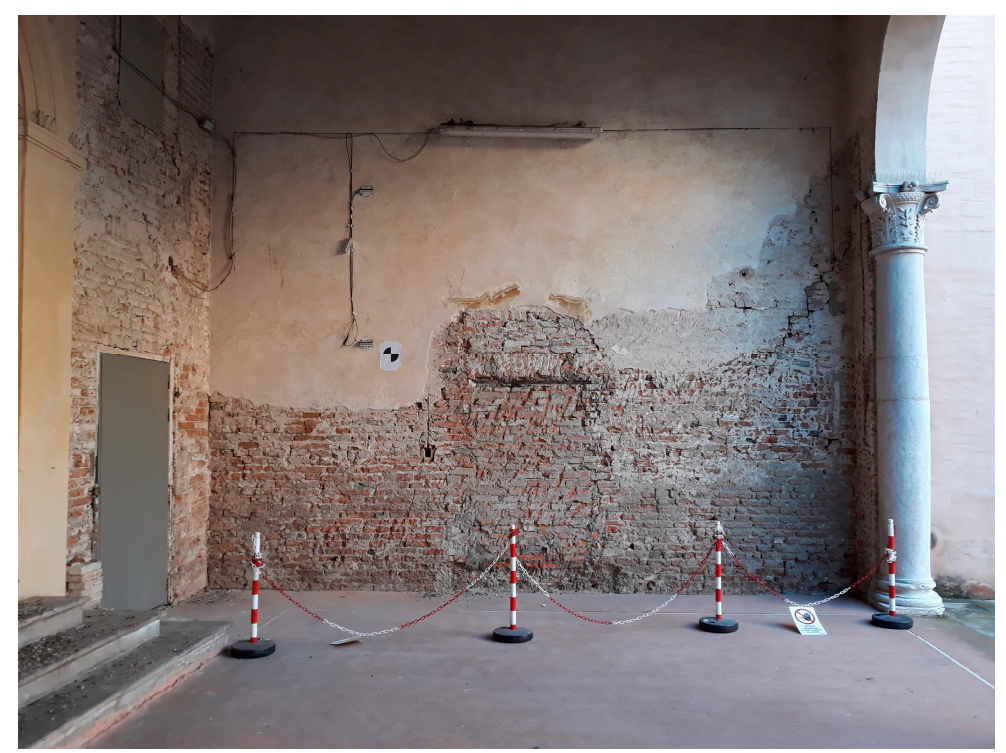

Figure 3. External view of the studied wall (internal courtyard under the porch) [6].

The test aims to analyse the hygrothermal performance of three thermal insulation technologies. According to the discussion of the technical worktable, the following materials were chosen. 
1. Stone wool boards: $40+60 \mathrm{~mm}$ thickness panels supported by their own steel frame and finished with gypsum boards $(12.5 \mathrm{~mm})$.

2. Cork boards: $50 \mathrm{~mm}$ thickness panels supported by their own timber structure, punctually fixed to the historic wall (very few anchor points) and finishing provided by gypsum fibre boards (12.5 mm);

3. Calcium silicate panels: $100 \mathrm{~mm}$ thickness panels glued, thanks to a mortar adhesive $8 \mathrm{~mm}$ thick, to the historic wall and given a $10 \mathrm{~mm}$ finishing mortar layer;

The paper presents the research activity related with the first described solution made by the use of the stone wool panels, widespread on the market even if herein tested without the vapour barrier commonly used when the stone wool panels are internally applied. Four different possible stratigraphies with stone wool were analysed during the technical worktable, with the aim to find the most suitable solution, both for the tests and to give interesting design directions for professionals that would like to use this material in future restoration and energy retrofit interventions. The analysed solution are: (i) use of a system composed by a gypsum board and/or gypsum fibre board jointed to a fibrous stone wool insulation panel, fastened to the wall by an adhesive mortar glue; (ii) stone wool insulation panel interposed between a metal frame (C-shape steel vertical profiles fixed to the wall thanks to U-shape steel adjustable brackets) with a gypsum board finish; (iii) stone wool insulation panel inserted between a metal frame (C-shape steel vertical profiles directly fixed to the wall) with a gypsum board finish; (iv) stone wool insulation panel interposed between a metal frame (C-shape vertical elements fixed to the floor) with a gypsum board finish. With respect to the previous solution, an additional insulation layer is inserted between the historic wall and the metal frame.

The first solution has been considered, by the heritage authorities, less suitable for the application on an historic wall, because of the necessity of the not reversible glue fastening system. For the same reason, the second solution has also been discarded due to the presence of the brackets, which requires an anchoring point piece by piece, affecting the conservation of the wall. The third solution is less intrusive for the historic walls, but the last option has been selected because it permits one to minimize the number of anchoring points between the wall and the dual system. Additionally, the additional insulation layer, compared to the third solution, allows solving the thermal bridge caused by the presence of the metal frame. All these aspects make this last option completely reversible and respectful for the historic wall.

Finally, the insulation stratigraphy selected by the technical worktable is composed by a first insulation panel $40 \mathrm{~mm}$ thick, a second insulation layer $60 \mathrm{~mm}$ thick, interposed between the metal frame, and the gypsum board finishing $(12.5 \mathrm{~mm})$.

Figure 4 shows the phase's sequence of the installation of the selected insulation system: in (a), the installation of the $C$ metal structure outdistanced from the wall to minimize the number of anchor points on the historic wall; in (b), the insertion of the additional insulation layer between the metal frame and the wall; finally, in (c), the interposition of the second stone wool set of panels between the vertical steel elements, then covered by the gypsum board finishing.

Concerning the original historic wall, the historical analysis and the verification of the analogies with the literature allowed identifying the geometric and dimensional characteristics of the bricks: they are the "Bolognese" type $(28 \times 14 \times 6 \mathrm{~cm})$, as commonly used in contemporary architecture in the same geographical area. The non-invasive survey through the cracks currently present in the wall made possible the identification of the dimensions of the joints, which, even if very variable, have an average thickness of $2 \mathrm{~cm}$. The overall thickness of the wall is $32 \mathrm{~cm}$, including the internal and external plaster.

The calculated U-value of the not refurbished wall is $1.44 \mathrm{~W} / \mathrm{m}^{2} \mathrm{~K}$ (estimated in steady state conditions), with the installed insulation system decreasing to $0.26 \mathrm{~W} / \mathrm{m}^{2} \mathrm{~K}$. The values used to calculate the U-value were the same of the hygrothermal simulation, and these are presented in Section 4.2. 
(a)
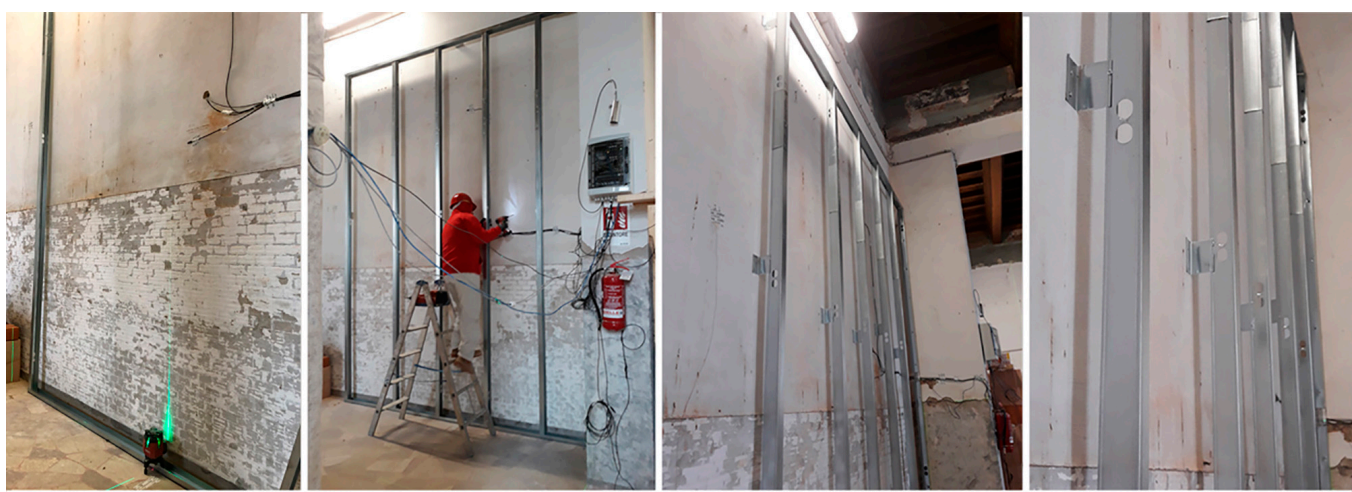

(b)
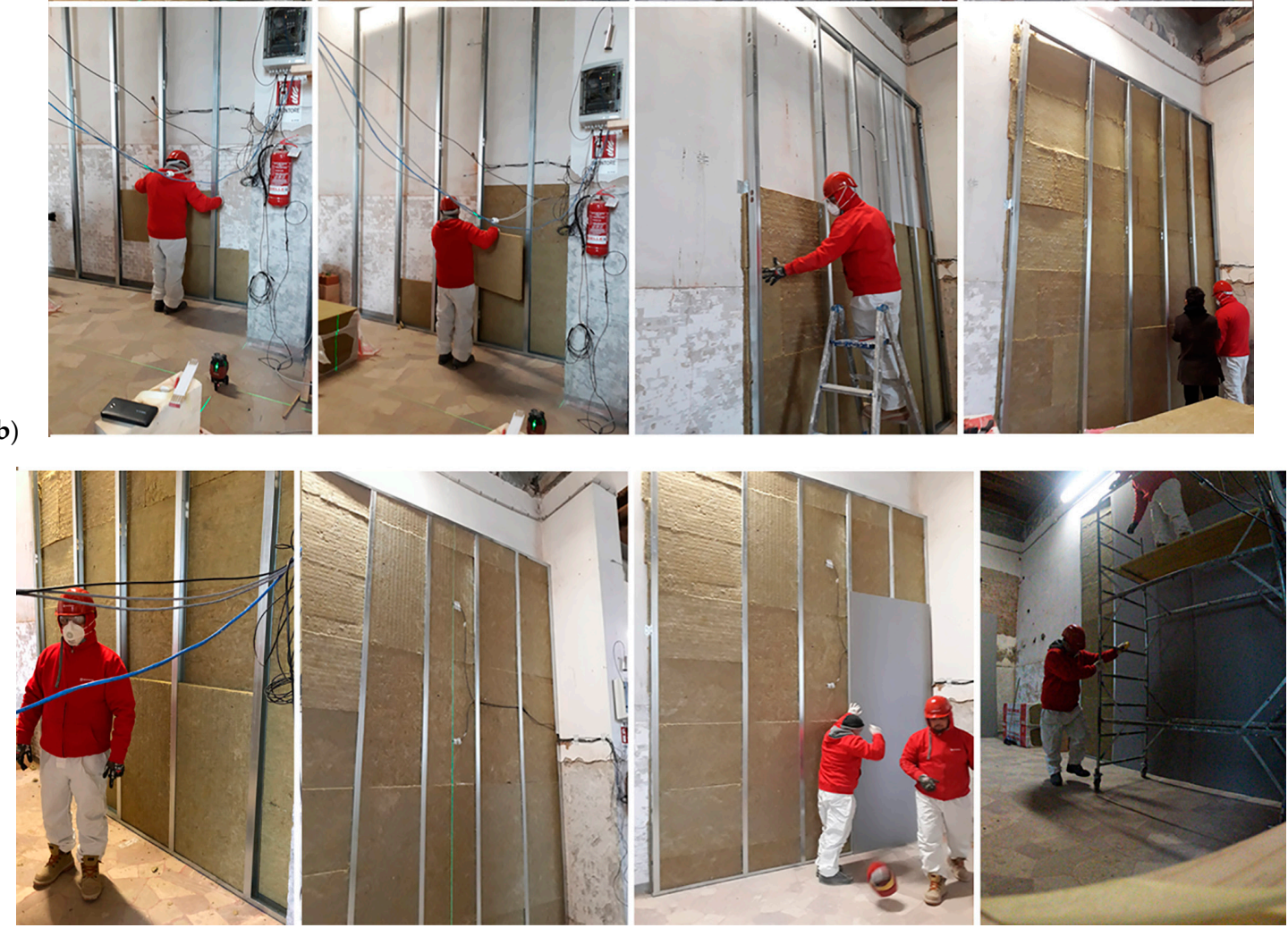

Figure 4. Installation of the selected insulation system.

\subsection{Monitoring System: New Metering Box and Hygrothermal Control Devices}

As pointed out earlier, inside the $700 \mathrm{~m}^{3}$ room, two smaller volumes $\left(25 \mathrm{~m}^{3} /\right.$ each) were constructed. In each volume (Figure 5), a standard indoor environment was set-up [indoor air temperature $\left(\left(\mathrm{T}_{\mathrm{a}}\right) \approx 20^{\circ} \mathrm{C}\right.$ and relative humidity $\left.(\mathrm{RH}) \approx 55 \%\right)$, according to the main international guidelines as EN ISO 7730 [42], EN ISO 13788 [43] or ISO 17772-1 [44]. Besides its special features (0.10 m high density stone wool insulation material, lined with a vapour barrier on the inside), each box was provided of a $2000 \mathrm{~W}$ heating convector (with 3 power levels), regulated by control system; two ultrasonic humidifiers (argo HYDRO digit, Argoclima S.p.A., Alfianello, Italy), $30 \mathrm{~W}$ each, self-regulated, which permitted controlling the indoor comfort parameters, Figure 6. 


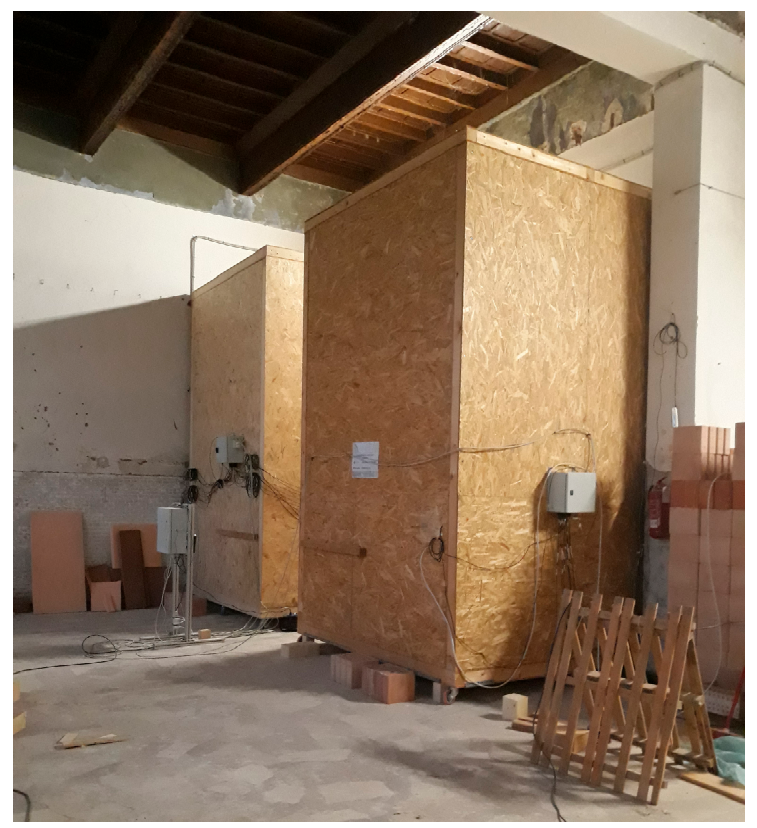

Figure 5. Internal view of the room, with the two boxes tied up to the studied wall.

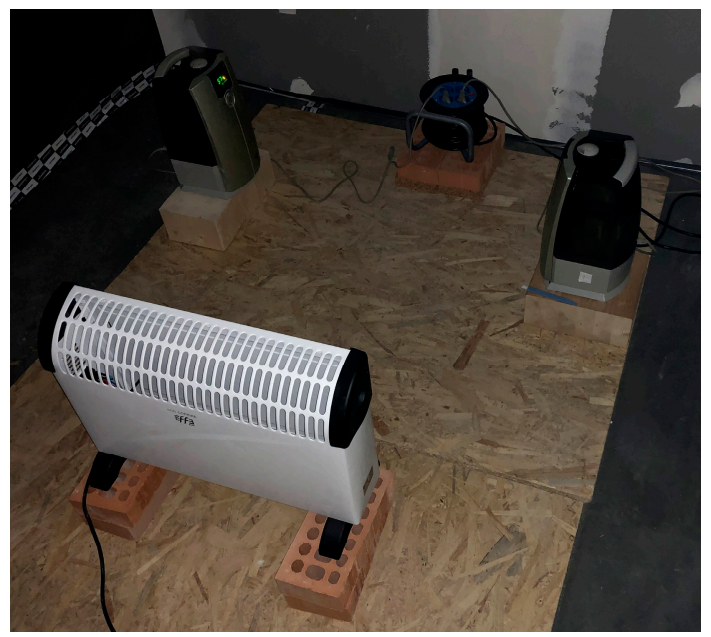

Figure 6. Hygrothermal control devices.

The newly developed metering boxes (construction technology fully described in [38]) were built from a modular timber structure and provided with wheels, so that they can be (dis)assembled, repositioned and/or hereafter used in other spaces/experiments (Figure 5). Besides minimizing the impacts of the experiment on the room's surrounding walls, these also permitted improving the experiment energy efficiency. The individual box dimensions $(2.50 \times 2.50 \times 4.01 \mathrm{~m}$ gross $)$ allow vertical heat stratification and were determined to permit the study of up to two insulation systems in parallel.

\section{Monitoring System and Period Campaign}

To perform the in situ monitoring campaigns, authors used a non-commercial setup: they have developed a specifically built-up sensing technology method for the hygrothermal assessment of historic walls [45], later upgraded and tuned [38] to fit the requirements of the HeLLo project [33]. In brief, a low-cost and conservation compatible technology based on temperature $(\mathrm{T})$ and relative humidity (RH) combined sensors (Telaire T9602, Amphenol Thermometrics, Inc. St. Marys, PA, USA) was used to measure the T-RH parameters of the environmental conditions (Figure 7a)—outdoor, inside the room and inside the box (herein considered the indoor environment), and in each point of 
the stratigraphy of the technology (Figure $7 \mathrm{~b}$ ). These sensors are connected and managed by a data acquisition system based on a master slave configuration [38]. Sensors have a typical temperature accuracy of $\pm 0.5^{\circ} \mathrm{C}$, if $\mathrm{T}$ varies between $20-40^{\circ} \mathrm{C}$, or up to $\pm 1{ }^{\circ} \mathrm{C}$ if $\mathrm{T}$ varies between $0-20{ }^{\circ} \mathrm{C}$. Relative humidity instead has an accuracy of $\pm 2 \%$, when $20 \leq \mathrm{RH}(\%) \leq 80$, decreasing up to $\pm 4 \%$ if $\mathrm{RH}$ varies between $0-20 \%$ or $80-100 \%$ [45].

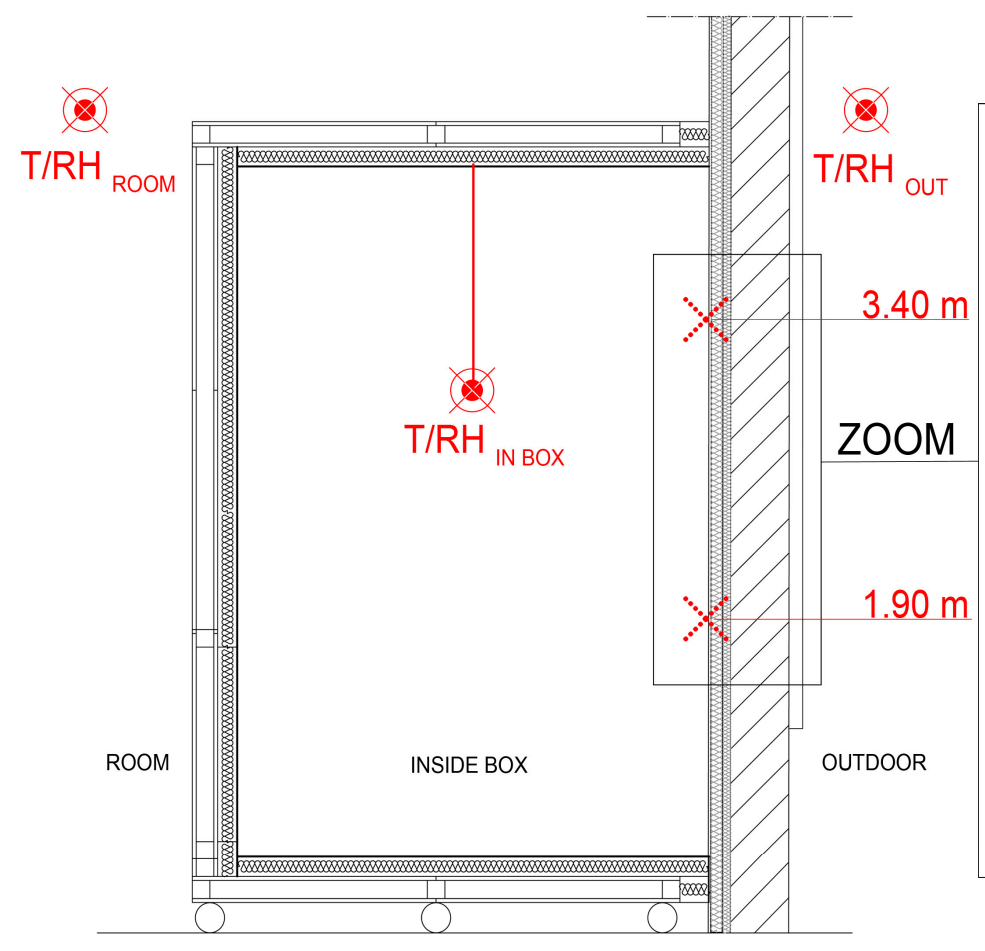

(a)

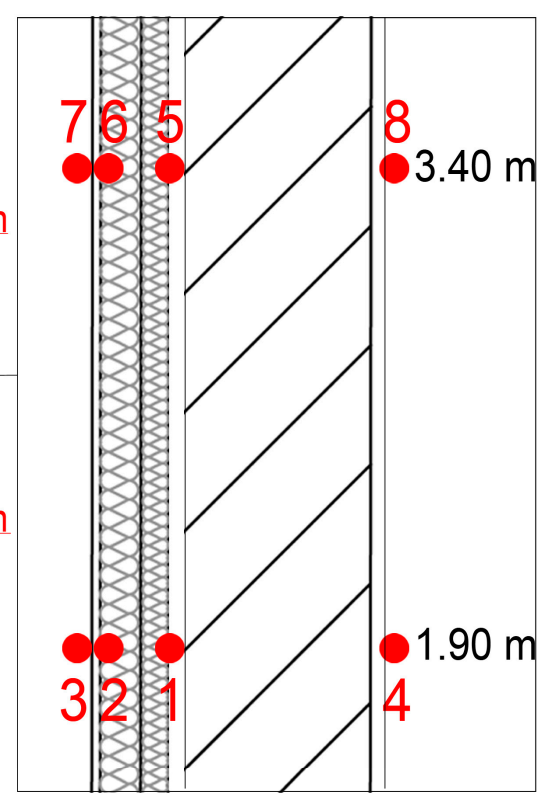

(b)

Figure 7. Scheme (vertical section) of the position of the monitoring sensors: (a) environmental conditions (room, inside box, outdoor); (b) wall stratigraphy.

Aiming to limit the influence of potential water capillarity absorption at the basis of the wall on the final results, sensors were strategically placed at a minimum height of $1.90 \mathrm{~m}$ from the floor. A second level of measuring points was added at $3.40 \mathrm{~m}$ (Figure 7). Although data were registered in different points of the stratigraphy, in this study, only the most probable condensation point—sensors 1 and 5 , Figure $7 \mathrm{~b}$, is deeply analysed.

The monitoring period, between 11 December 2019 and 11 March 2020 is fully presented and described in Section 5.

Data were logged every $1 \mathrm{~min}$. The results presented in Section 5 correspond to $10 \mathrm{~min}$ averages. The monitoring campaign, still on-going, begun during the 2019-2020 Ferrara's heating season (the hygrothermal control devices, Figure 6, were started on 23 October). In the current paper a long-term period of 3 months is shown, corresponding to the period between 11 December 2019 and 11 March 2020.

\section{Hygrothermal Simulation Set-Up}

\subsection{Boundary Conditions}

All the simulations are performed in accordance with EN 15026 [46], so they include the following physical phenomena: heat storage, heat conduction, moisture storage, liquid water convective transport and vapor diffusion. Simulation are performed using the software Delphin 6.0.20 [34], developed at the Technical University of Dresden (TUD) by the Building Climatology Department. The following 
section presents hygrothermal simulations, starting from the monitored internal and external climatic dataset (Section 4.1), to the geometric modeling and to the hygrothermal proprieties of the selected materials (Section 4.2).

The used climatic dataset was monitored in the framework of the mentioned research project HeLLo [33] and included hourly data of T and RH of the surrounding air, both for external and internal environment. Rain and solar action were not considered, as the studied wall is located under a porch of the courtyard of the building, so it is not exposed. Figure 8 shows the in situ monitored hourly data of $\mathrm{T}$ and RH for the internal and external climate, related to the period between 11 December 2019 and 11 March 2020, used also for the model validation.
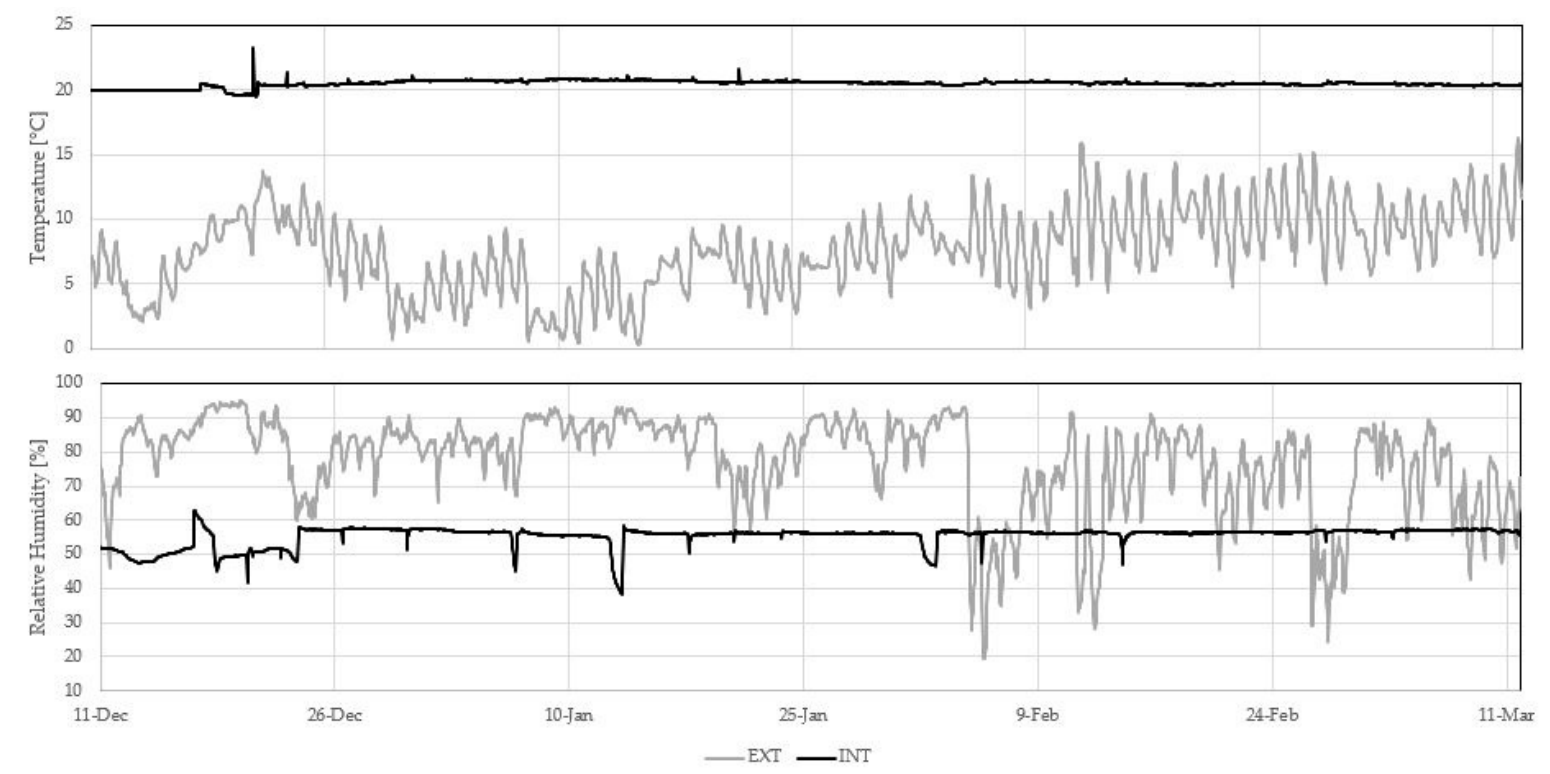

Figure 8. Hourly monitored data between 11 December 2019 and 11 March 2020, for external and internal climate: temperature (top panel) and relative humidity (bottom panel).

Anyway, to ensure a complete yearly dataset of the hygrothermal simulation, the residual months had to be integrated: regarding the external weather, an additional monitoring right in the adjoining garden was used, related to 2017 (provided by Prof. Michele Bottarelli, University of Ferrara). A preliminary analysis showed the compatibility of such data with the monitored dataset. Regarding interior climate, the residual period was calculated from the outdoor climate data, according to EN 15026 [46] and the WTA sheet 6.2 [47] adaptive climate model. Finally, all the main climatic coefficients and parameters, used for the simulation are presented in Table 1.

Table 1. Relevant parameters and coefficients used for the hygrothermal simulations, for external and internal boundary conditions.

\begin{tabular}{|c|c|c|c|}
\hline & Quantity & Value & Unit \\
\hline \multirow{2}{*}{ 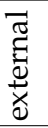 } & Heat transfer coefficient (exterior surface), $h_{c, \text { ext }}$ & 12 & {$\left[\mathrm{~W} / \mathrm{m}^{2} \mathrm{~K}\right]$} \\
\hline & Vapour diffusion coefficient (exterior surface) & $7.5 \times 10^{-8}$ & {$[\mathrm{~s} / \mathrm{m}]$} \\
\hline \multirow{4}{*}{ 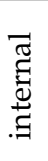 } & Temperature range for interior clin & $20-25$ & {$\left[{ }^{\circ} \mathrm{C}\right]$} \\
\hline & Relative humidity range for interior climate (normal moisture load) & $35-65$ & {$[\%]$} \\
\hline & Heat transfer coefficient (interior surface), $h_{c, \text { int }}$ & 8 & {$\left[\mathrm{~W} / \mathrm{m}^{2} \mathrm{~K}\right]$} \\
\hline & Vapour diffusion coefficient (interior surface) & $3 \times 10^{-8}$ & {$[\mathrm{~s} / \mathrm{m}]$} \\
\hline
\end{tabular}




\subsection{Two-Dimensional Model}

The hygrothermal model was designed on the basis of the horizontal section of the historic monitored wall (Figure 7). A two-dimensional (2D) hygrothermal model was constructed for the dynamic simulation from the horizontal section of the historic wall, as presented in Figure 9: in (a), the architectural survey is visible; while in (b), the 2D transport model used for dynamic simulations is found (the interfaces between the materials are indicated from A (external) to E (internal side)).

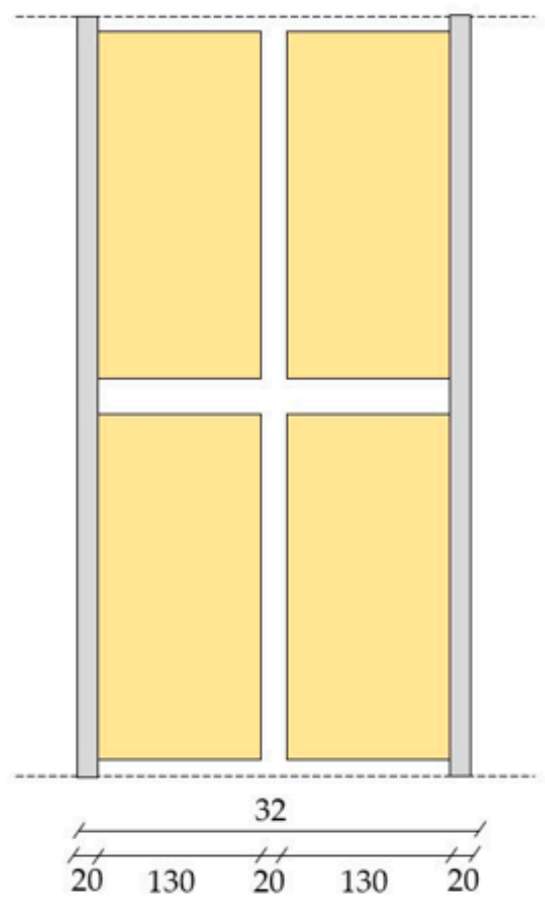

(a)

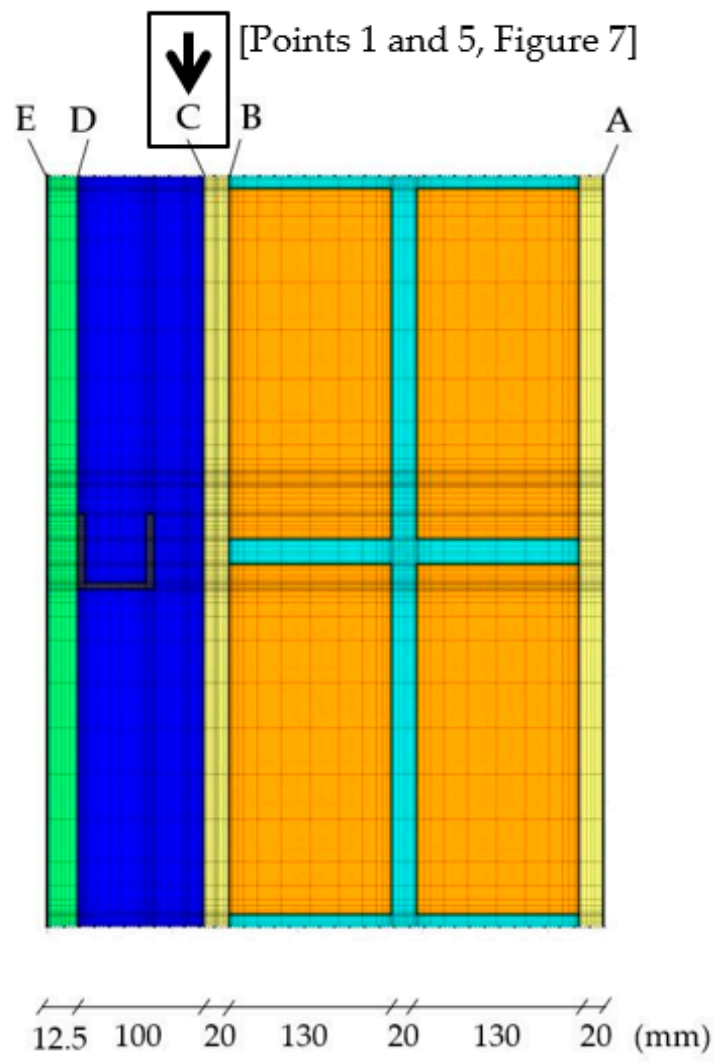

(b)

Figure 9. Two-dimensional model deducted for the dynamic simulation.

All the hygrothermal data regarding building materials are taken from Delphin's Material Database 6.0.20 [48] and were determined experimentally at the Climatology Laboratory at the University of Dresden. The building materials were selected from a specific historical cluster. In particular, brick and exterior plaster data refer to historic materials coming from a case study in Bologna and measured within the 3enCult European Project [14]. The hygrothermal characterization of the used stone wool, instead, comes from the material installed by the company involved in the HeLLo project. The characterization of the mentioned material for the dynamic calculation was performed in the laboratories of the Fraunhofer IBP (Institut of Building Physics) [49]; for this reason, data were appropriately formatted to fit the material characterization of the Delphin ${ }^{\circledR}$ database [48]. The main hygrothermal properties for all the used materials are presented in Table 2 and Figure 10. On the top of Table $2\left(^{*}\right)$, the materials that were characterized in the framework of the 3enCult Project are presented [14], while in Figure 10, the moisture storage function of the materials is shown: in (a), the moisture content is shown $-\theta_{1}(p c)$; in (b), the liquid water conductivity as a function of the capillary pressure $\mathrm{Kl}(\mathrm{pc})$ is shown. In both, (a) and (b), the three vertical lines refer to the $\mathrm{RH}$ values of $50 \%, 95 \%$ and $99 \%$. 
Table 2. Main hygrothermal properties of the chosen materials.

\begin{tabular}{cccccccc}
\hline Material & $\begin{array}{c}\text { ID Delphin } \\
\text { DB }\end{array}$ & $\begin{array}{c}\rho \\
{\left[\mathbf{k g} / \mathbf{m}^{3}\right]}\end{array}$ & $\begin{array}{c}\mathbf{C}_{\mathbf{p}} \\
{[\mathbf{J} / \mathbf{K g K}]}\end{array}$ & $\begin{array}{c}\boldsymbol{\theta}_{\text {por }} \\
{\left[\mathbf{m}^{\mathbf{3}} / \mathbf{m}^{\mathbf{3}}\right]}\end{array}$ & $\begin{array}{c}\lambda_{\text {dry }} \\
{[\mathbf{W} / \mathbf{m K}]}\end{array}$ & $\begin{array}{c}\mu_{\text {dry }} \\
{[-]}\end{array}$ & $\begin{array}{c}\mathbf{A}_{\mathbf{w}} \\
{\left[\mathbf{k g} / \mathbf{m}^{\mathbf{2}} \mathbf{s}^{\mathbf{0 5}}\right]}\end{array}$ \\
\hline Lime Mortar & 143 & 1570 & 1000 & 0.408 & 0.7 & 11.0 & 0.176 \\
Historical Brick $\left(^{*}\right)$ & 532 & 1759 & 1092 & 0.336 & 0.624 & 24.5 & 0.184 \\
Lime plaster External (*) & 520 & 1604 & 869 & 0.395 & 0.69 & 19 & 0.179 \\
Lime plaster Internal & 629 & 1498 & 802 & 0.435 & 0.412 & 9.3 & 0.018 \\
Stone wool & - & 70 & 1030 & 0.950 & 0.033 & 1 & - \\
Steel & 238 & 7800 & 470 & - & 47 & - & - \\
Gypsum board & 599 & 745 & 1826 & 0.719 & 0.177 & 11 & 0.179 \\
\hline
\end{tabular}

Note: Density $(\rho)$, Specific heat $(\mathrm{Cp})$, porosity $\left(\theta_{\text {por }}\right)$, thermal conductivity $\left(\lambda_{d r y}\right)$, vapour resistance $\left(\mu_{d r y}\right)$ and capillary absorption coefficient (Aw).

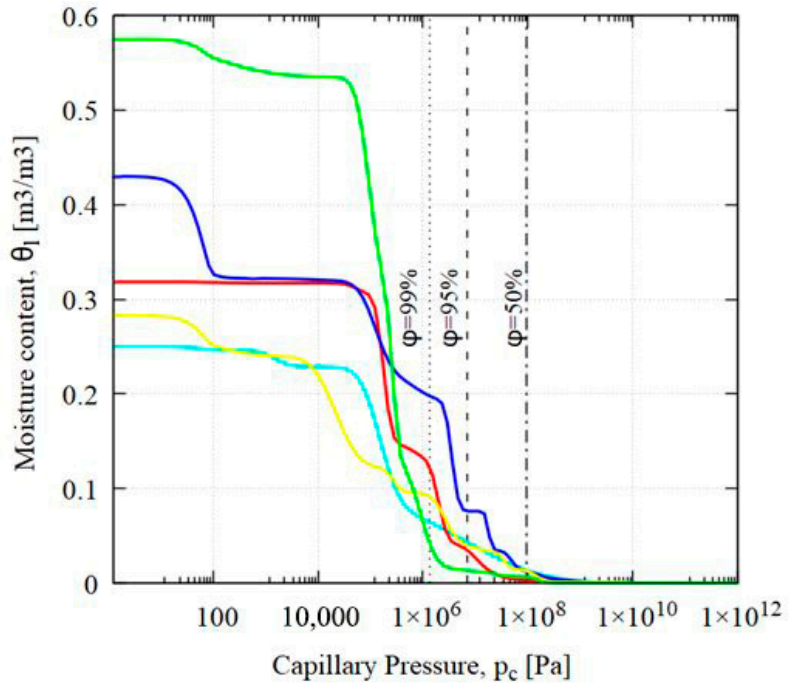

(a)

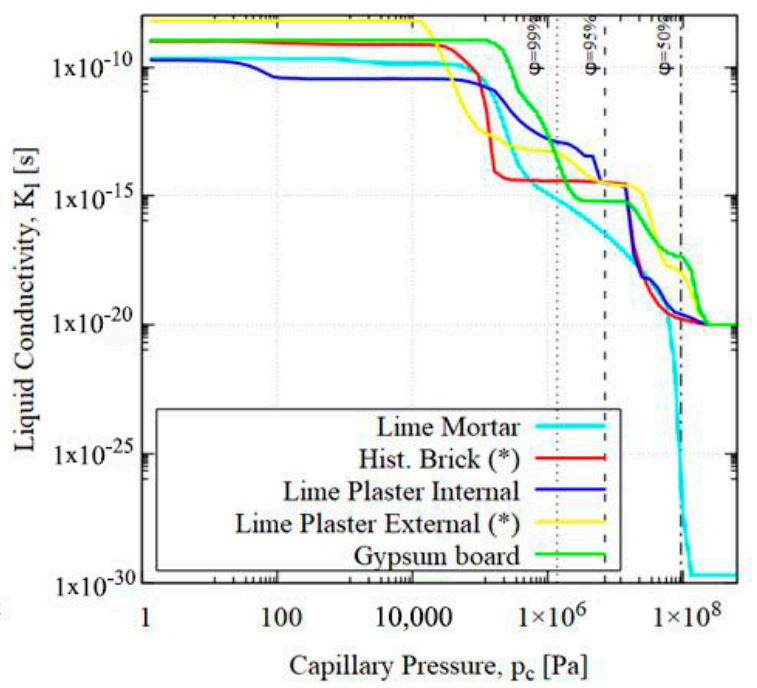

(b)

Figure 10. Moisture storage function of the materials used for the $2 \mathrm{D}$ simulation.

\subsection{Selection of Outputs}

The selected outputs to analyze the hygrothermal assessment were based on the recommendations of the WTA leaflet 6.5 [50] and on the possibility of comparing the simulated data with the monitored results. Although different points of the stratigraphy were simulated (Figure 9), here, only $\mathrm{T}$ and $\mathrm{RH}$ of the cold surface of the insulation, and most probable condensation point (Point C, Figure 9), were analysed, alike for the monitored data. In addition to the monitored period, RH was studied for the dry months (10 December-7 August).

The total moisture content of the wall was observed, to determine when the simulation reaches periodic behavior and is not influenced any more by the chosen initial conditions. Then, the evaluation period starts.

All the outputs were evaluated through a spatial average, to obtain a unique value for each time step.

\section{Results}

\subsection{In Situ Monitoring}

Figures 11 and 12 show the 10 min averaged values of measured $\mathrm{T}\left({ }^{\circ} \mathrm{C}\right)$ and $\mathrm{RH}(\%)$ at the most probable condensation point (sensors 1 and 5, Figure 7b), i.e., the point between the insulation panels and the historic wall, at both heights $1.90 \mathrm{~m}$ and $3.40 \mathrm{~m}$. As the measured parameters inside the room 
where the experiment is being developed follow the outdoor conditions, these would not add any specific value to the analysis; therefore, authors deliberately did not present them in these graphs.

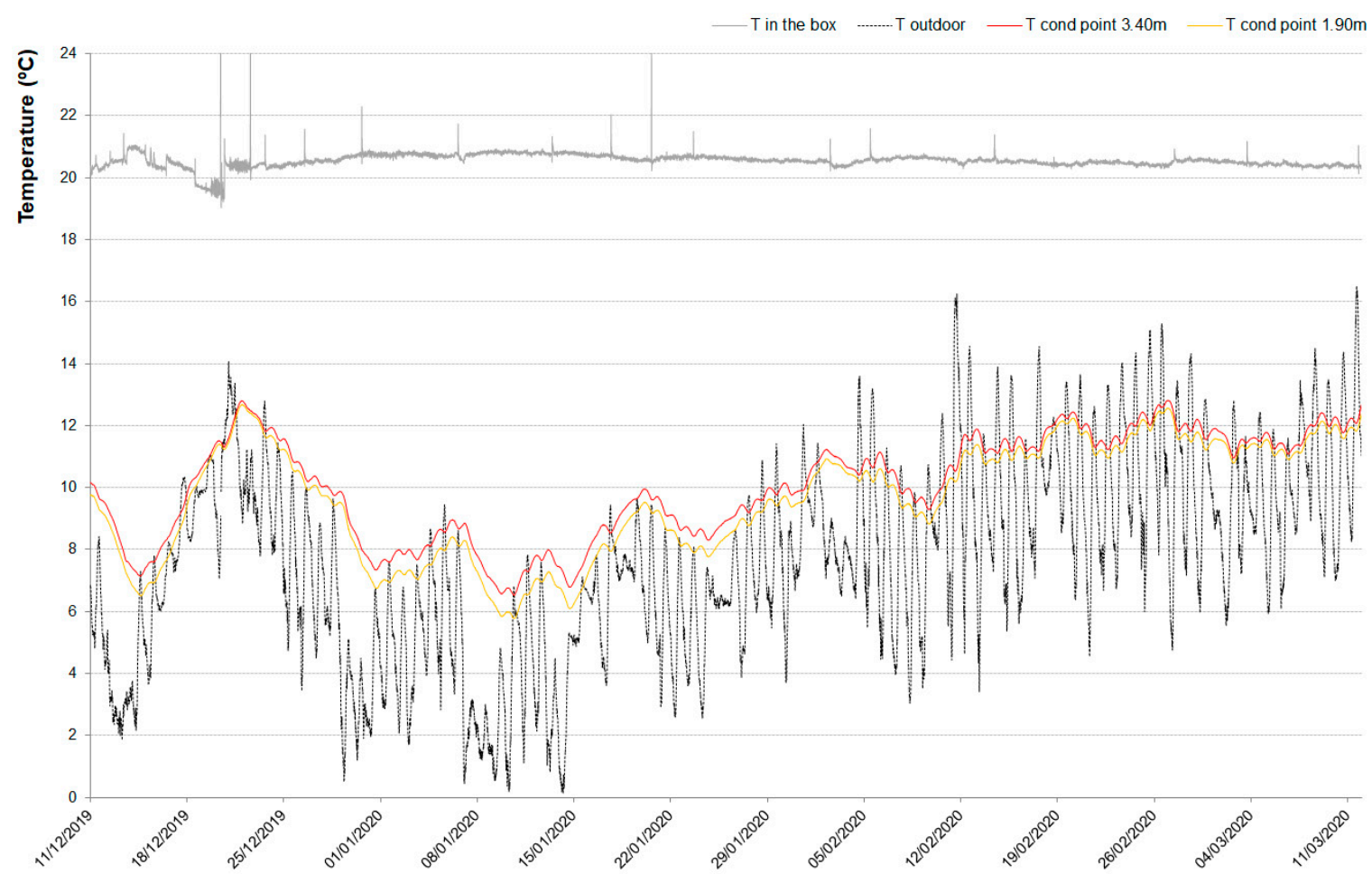

Figure 11. Graphical representation of the T values between 11 December 2019 and 11 March 2020.

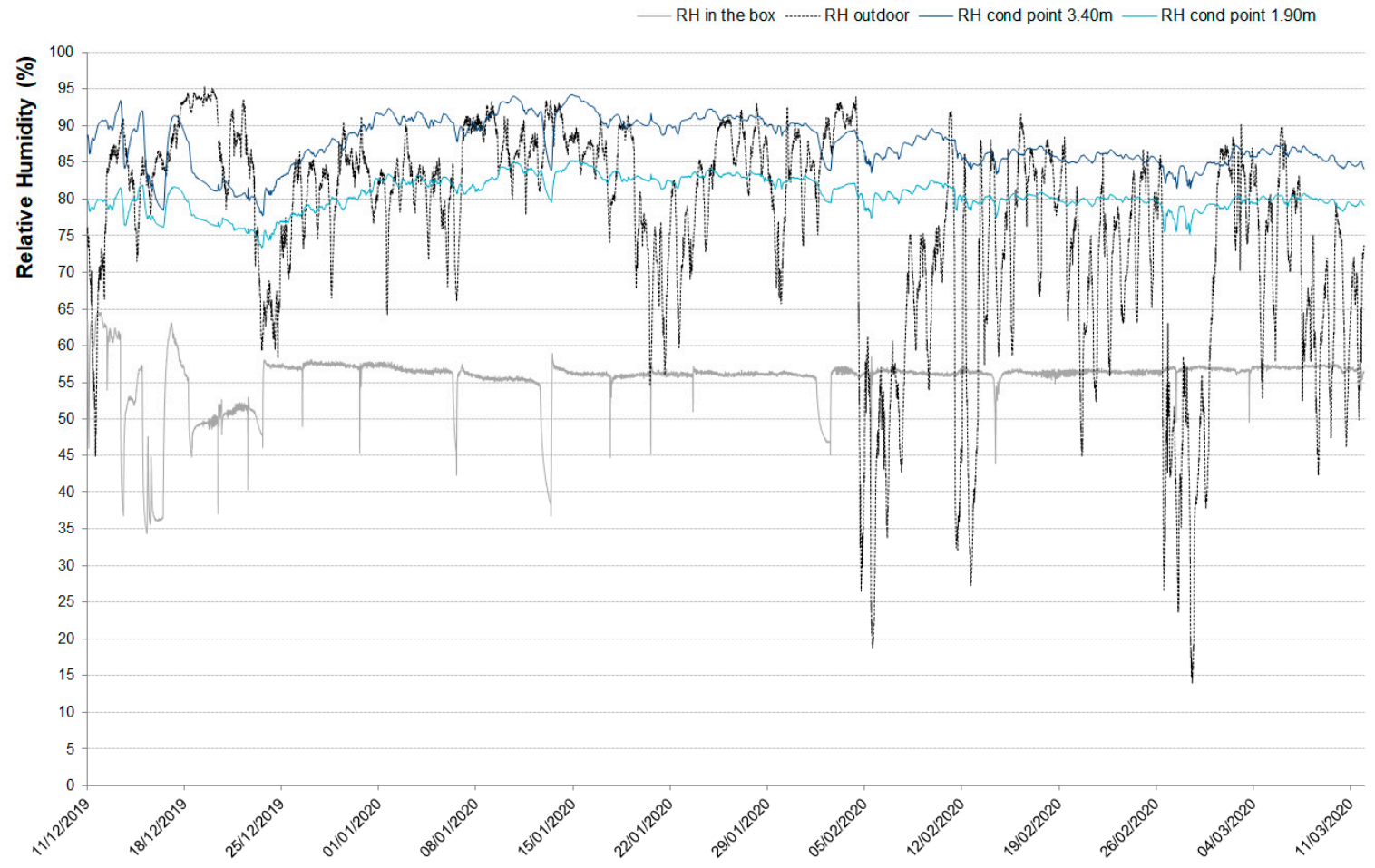

Figure 12. Graphical representation of the relative humidity (RH) values between 11 December 2019 and 11 March 2020.

As can be observed (Figure 11), $\mathrm{T}\left({ }^{\circ} \mathrm{C}\right)$, values measured on the inner side of the wall (just before the insulation, sensors 1 and 5, Figure 7b), clearly follow the outdoor trend. At the coolest moments, $\mathrm{T}$ was 
always above $5{ }^{\circ} \mathrm{C}$, therefore the risk of frost damage did not occur. This data should be cautiously considered-in a colder winter, a different result could be expected. The maximum deviation between the line $\mathrm{T} 1.90 \mathrm{~m}$ and $\mathrm{T} 3.40 \mathrm{~m}$ is $\Delta \mathrm{T}_{\max }=0.8^{\circ} \mathrm{C}$ and has no significance, since the difference of values is within the accuracy of the $\mathrm{T}$ sensors.

The risk of interstitial condensation, even if limited, was present. According to the measured data authors would be tempted to state it did not happen, as RH maximum was $94.2 \%$, measured at $3.90 \mathrm{~m}$. Nonetheless, considering sensors accuracy, previously declared, it might have occurred. Through the observation of Figure 12, there seems to be a trend of a drying out process, as RH values were getting slightly lower in the beginning of March. Nonetheless, this hypothesis can only be discussed based on the simulation (Section 5.2), as for present monitored data do not allow one to confirm it. The maximum deviation between the line $\mathrm{RH} 1.90 \mathrm{~m}$ and $\mathrm{RH} 3.40 \mathrm{~m}$ is $\Delta \mathrm{RH}_{\max }=12 \%$. In this case, it is significant, since the difference of values is beyond the accuracy of the RH sensors. This may be caused by several factors depending on the historic wall: e.g., the non-homogeneity of materials, possible presence of cracks or the limited adherence of the insulation materials to the out-of-line wall.

Concerning the internal condition of the box, an observation can be outlined. Some insignificant peaks (in terms of time and amplitude) can be observed on the $\mathrm{RH}$ graph inside the box. These correspond to moments of maintenance procedures of the monitoring campaign (i.e., when the box was open and the conditions of the air inside the box naturally mixed with those of the room). These events do not influence the average internal conditions and the test.

\subsection{Hygrothermal Simulation}

The simulation reaches a periodic behavior in the second simulated year. The graph (Figure 13) shows the monitored period (11 December-11 March), plus the drying period for the investigated wall. Hourly averaged simulated values of $\mathrm{T}\left({ }^{\circ} \mathrm{C}\right)$ and $\mathrm{RH}(\%)$ are shown at the most critical part of the section [51], point C (Figure 9).

As can be observed, at the coolest moments, $\mathrm{T}\left({ }^{\circ} \mathrm{C}\right)$ was always above $5^{\circ} \mathrm{C}$, therefore, the risk of frost damage was not evidenced.

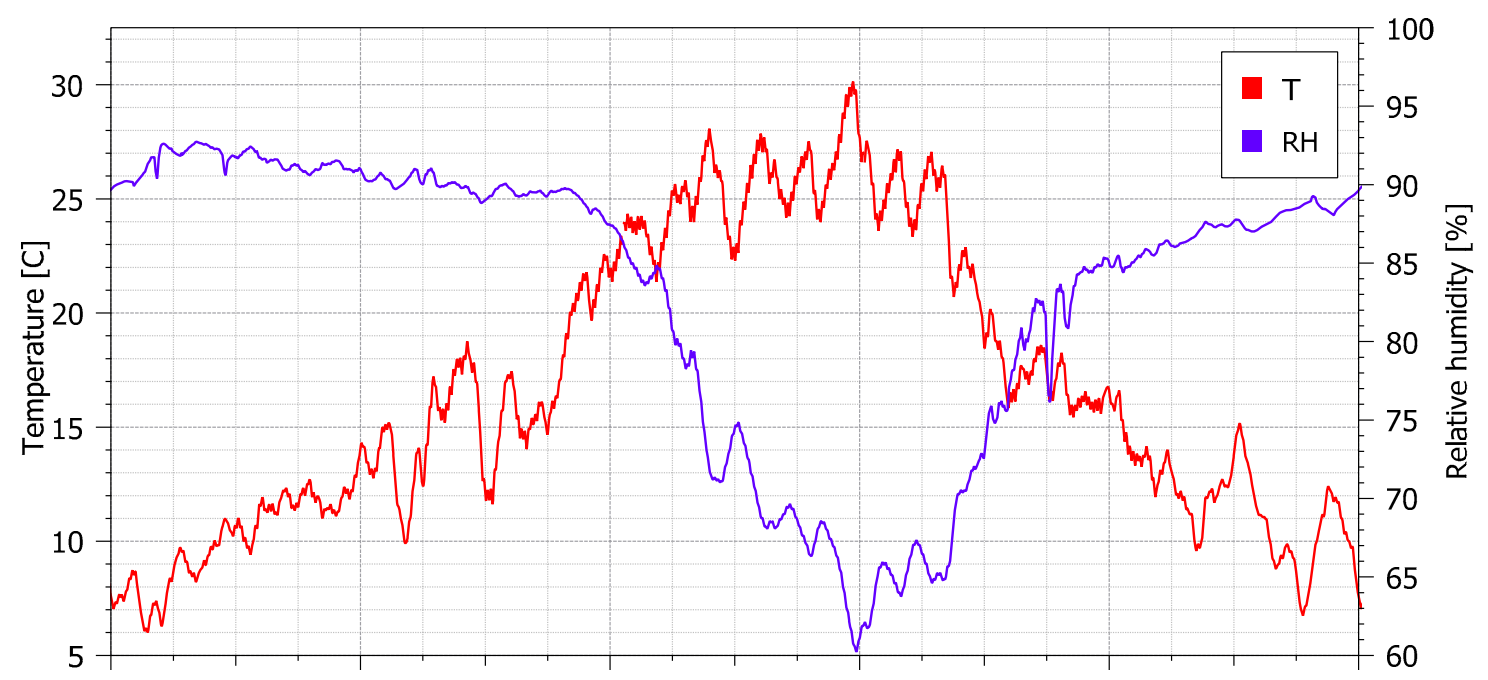

Figure 13. $\mathrm{T}\left({ }^{\circ} \mathrm{C}\right)$ and $\mathrm{RH}(\%)$ profiles of the simulated wall in point $\mathrm{C}$, during the 2 nd year of simulation.

Concerning RH (\%), although high values are exhibited during the studied wet period (11 December-11 March), it remains below 95\%, the condensation risk threshold defined by the WTA Leaflet 6.5 [50], which indicates the absence of condensate. Moreover, Figure 13 illustrates a strong decrease of RH from the wet to dry period of the year, emphasizing a significant reduction of moisture content in summer. It reaches the driest value on 7 August. This fact is also visible in Figure 14, where a profile of RH during the most critical and the most favorable hours of the year are 
shown for the studied wall. In particular, in terms of moisture accumulation, it can be observed in Figure 14a the wall section during the wettest hour (on 26 January at 00:00) and in Figure 14b, the wall section during the driest hour (on 7 August at 12:00).

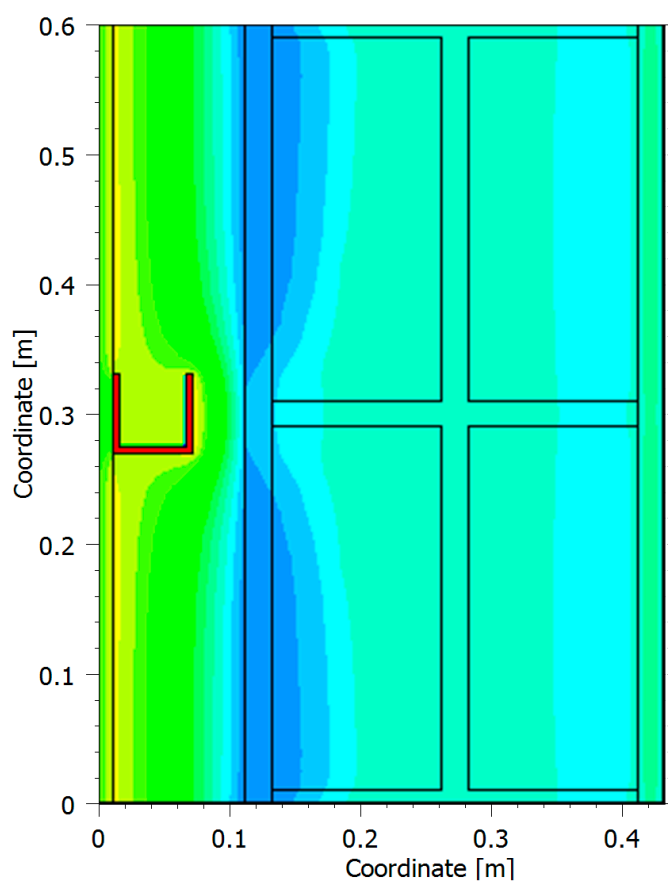

(a)

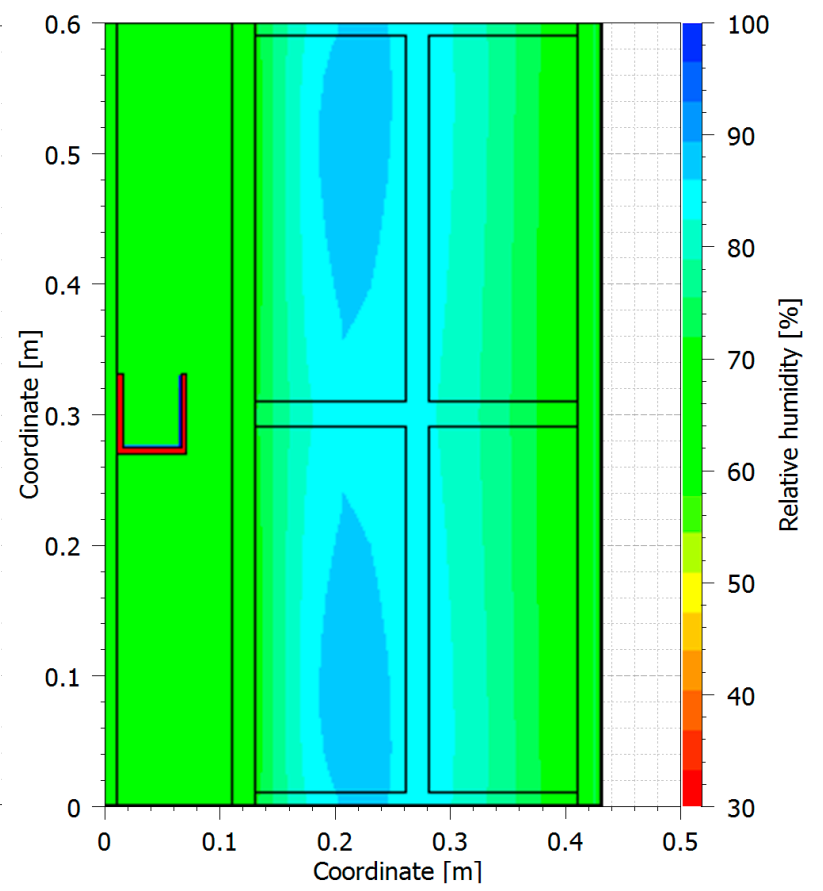

(b)

Figure 14. RH profile of the original simulated wall during the most critical (a) and the most favourable (b) hours of the year.

\section{Discussion}

\subsection{Comparison of Monitored and Simulated Results}

For the analysed 3-month period (11 December 2019 to 11 March 2020), several observations can be pointed out concerning both monitored and simulated data at point $C$ (Figure 9) of the stratigraphy, namely:

- The average temperature values do practically coincide. Average $\mathrm{T}_{\text {simul }}=9.9{ }^{\circ} \mathrm{C}$, while average $\mathrm{T}_{\text {monit }}=[9.7-10.1]^{\circ} \mathrm{C}$. Considering the accuracy of the sensors, it can be declared that averaged $\mathrm{T}_{\text {simul }}=\mathrm{T}_{\text {monit }} ;$

- Both monitored and simulated values pointed to lowest $\mathrm{T}\left({ }^{\circ} \mathrm{C}\right)$ value $>5{ }^{\circ} \mathrm{C}$, i.e., the risk of frost damage was not evidenced;

- Concerning RH, data must be observed more carefully, as monitored RH values at $3.40 \mathrm{~m}$ and $1.90 \mathrm{~m}$ differed more expressively than $\mathrm{T}$. average monitored $\mathrm{RH}$ values varied between $80.6-87.6 \%$, at $1.90 \mathrm{~m}$ and $3.40 \mathrm{~m}$ respectively, while average $\mathrm{RH}_{\text {simul }}=90.8 \%$. Bearing in mind the accuracy of the sensors, it can be stated that the average simulated values fit the average RH values measured at $3.40 \mathrm{~m}$. The similarity of the simulated and monitored values is further reinforced by other statistical data: at $3.40 \mathrm{~m}$, only $25 \%$ of data (Q3) was above $90.4 \%$. The difference of monitored values between sensors at $1.90 \mathrm{~m}$ and $3.40 \mathrm{~m}$, currently attributed to the possible presence of cracks, i.e., wall inhomogeneity, does not allow a fair comparison between RH at $1.90 \mathrm{~m}$ with the simulated data;

- These comments are also grounded on the synthesis presented on Table 3;

- Grounded on the aforementioned data, the authors considered that the simulation model was validated. 
Table 3. Synthesis of the averaged hygrothermal data.

\begin{tabular}{cccc}
\hline Title & Simulation & Monitoring at $\mathbf{3 . 4 0 ~} \mathbf{m}$ & Monitoring at $\mathbf{1 . 9 0} \mathbf{~ m}$ \\
\hline $\mathrm{RH}(\%)$ & 90.8 & 87.6 & 80.6 \\
$\mathrm{~T}\left({ }^{\circ} \mathrm{C}\right)^{2}$ & 9.9 & 10.1 & 9.7 \\
\hline${ }^{1}$ At $80 \%$, sensors accuracy $\pm 2 \%$; at $90 \%, \pm 3 \% .{ }^{2}$ At $10{ }^{\circ} \mathrm{C}$, sensors accuracy $\pm 0.5^{\circ} \mathrm{C}$.
\end{tabular}

\subsection{Variation of the Simulation}

\subsubsection{New Models and Additional Outputs}

Despite the absence of interstitial condensation suggested by the simulation for the given outdoor climate, but given the reasonable doubt pointed out by the monitored data, further simulation scenarios and outputs were explored.

The insulation system, described in Section 2.2, was simulated including different thickness of the stone wool (additionally to the installed $10 \mathrm{~cm}$, also $6 \mathrm{~cm}$ and $8 \mathrm{~cm}$ ) and the use of two gypsum boards as internal finishing (against the single layer installed). These simulations also allowed one to explore whether the biggest impact in moisture accumulation is credited to the ingress of moisture from the internal side, or to the reduction of the drying potential of the wall due to the interior insulation. Thus, considering the pros and cons, this evaluation could point to the most efficient retrofitting strategy, between reducing the thickness of insulation or improving the vapour resistance of the internal finishing.

Additionally, in order to quantify the performances of the insulation system and the cons of reducing its thickness in the first and second variant scenarios $(6-8 \mathrm{~cm})$, heat losses were calculated.

The heating period is defined as the part of the year in which the sinusoidal fit of the daily outdoor temperature is smaller than $10{ }^{\circ} \mathrm{C}$ [52]. For the selected dataset, this period corresponds to the days from 15 October to 15 April. Finally, a profile of the temperature in point $C$ (Figure 9) was studied to compare different retrofit scenarios. A new moisture accumulation analysis was performed and the reaching periodic behaviour was also verified for the simulated variants.

\subsubsection{Thermal Simulation}

Figure 15 reports $\mathrm{T}\left({ }^{\circ} \mathrm{C}\right)$ in the cold side of insulation (point $\mathrm{C}$, Figure 9), with a focus on the different simulation scenarios of 6-8 and $10 \mathrm{~cm}$ of stone wool (left panel). In order to quantify the expected thermal losses, heat flux during the simulated heating period is presented in the right panel.

The cumulative thermal losses for the studied heating period (15 October-15 April) are $96.27 \mathrm{kWh} / \mathrm{m}^{2}$ for the uninsulated wall, $15.79 \mathrm{kWh} / \mathrm{m}^{2}$ for the real case scenario $(10 \mathrm{~cm}$ of stone wool), $19.74 \mathrm{kWh} / \mathrm{m}^{2}$ for the $8 \mathrm{~cm}$ and $21.96 \mathrm{kWh} / \mathrm{m}^{2}$ for $6 \mathrm{~cm}$ of stone wool as an insulation layer.

Figure 16 includes a thermal profile of the wall during the coldest day of the year (on 26 January at 00:00), for the most and least insulated scenarios, respectively $10 \mathrm{~cm}$ [Figure 16a] and the $6 \mathrm{~cm}$ (Figure 16b) of stone wool.

\subsubsection{Moisture Accumulation Analysis}

Figure 17 shows RH behind the insulation during the monitored period (11 December-11 March), plus the drying period (12 March-7 August) for the investigated wall. Moreover, scenarios with 6-8 cm of stone wool and $10 \mathrm{~cm}$ with two gypsum boards as the internal finishing layer are also presented, in order to compare the impact of different interventions. All the scenarios confirmed the initial simulation results: a strong decrease of $\mathrm{RH}$ from the wet to dry period of the year, emphasizing a significant reduction of moisture content in the summer. 

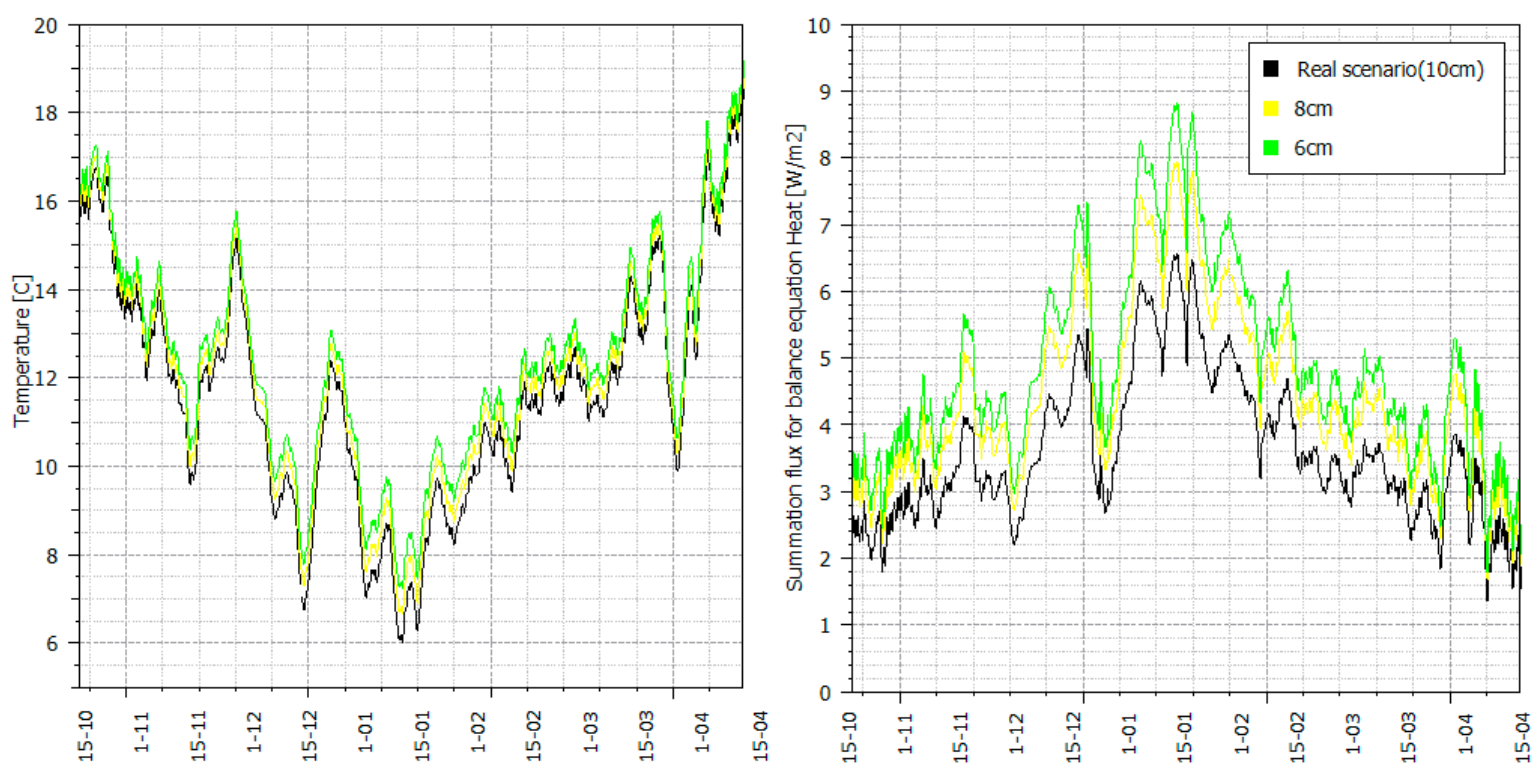

Figure 15. Left panel: hourly value of temperature in Point C (Figure 9). Right panel: hourly value of heat loss for the simulated walls, both during the heating period (15 October-15 April). Design scenarios of $6-8 \mathrm{~cm}$ of stone wool are included.

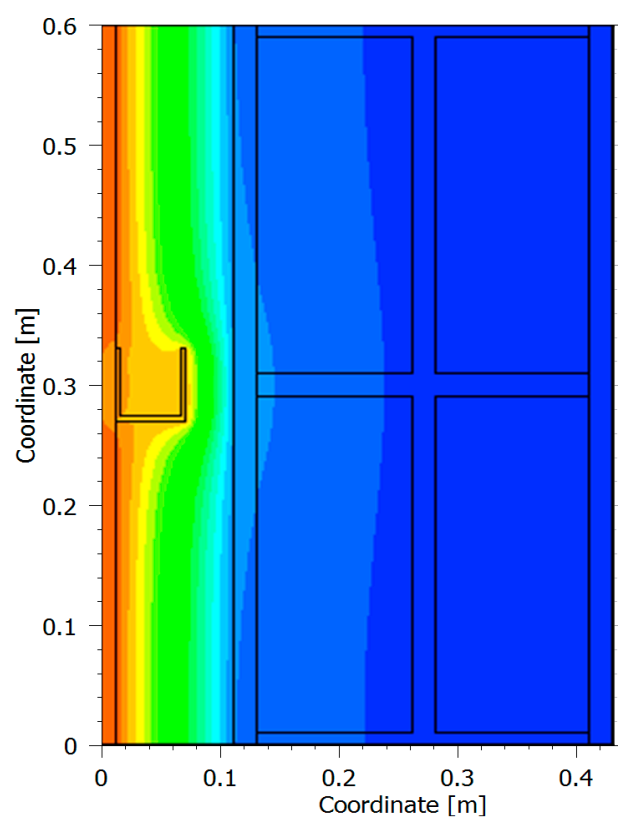

(a)

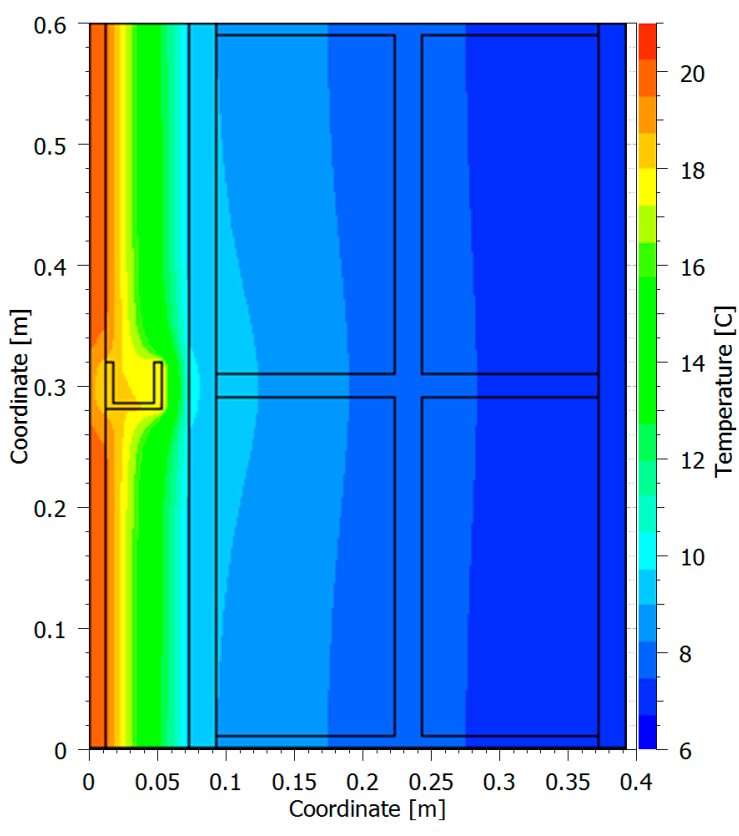

(b)

Figure 16. Temperature profile of the simulated wall during the coldest hour for $10 \mathrm{~cm}$ and $6 \mathrm{~cm}$ insulation scenarios. 


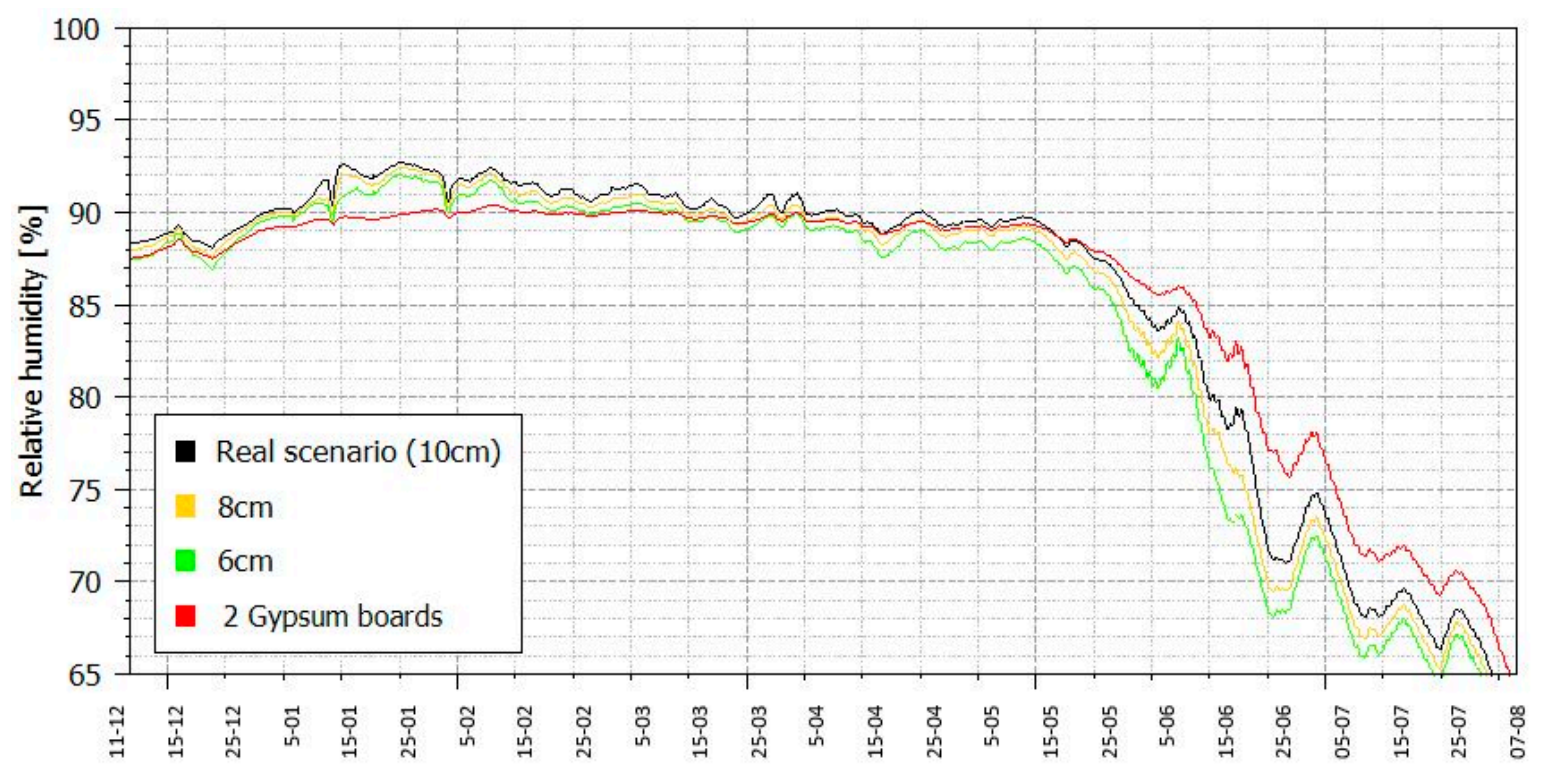

Figure 17. $\mathrm{RH}$ in point $\mathrm{C}$ (Figure 9) during the period 11 December-7 August, for the simulated wall. Design scenarios of 6-8 cm of stone wool and 2 gypsum boards as interior finishing are included.

\subsubsection{Discussion of the Various Simulation Outputs}

With respect to the real $10 \mathrm{~cm}$ insulated case, the thermal analysis of 6-8 $\mathrm{cm}$ scenarios (Section 6.2.2) has quantified the expected decrease of energy performance, due to the reduction of the insulation thickness, and the increase of $\mathrm{T}\left({ }^{\circ} \mathrm{C}\right)$ behind the insulation layer (point $\mathrm{C}$, Figure 9), shown in Figure 15 (left panel) as an effect of the higher loss of heat reported and quantified in Figure 15 (right panel); also, in Figure 16 the thermal effect of insulation on the existing wall is visible: the use of $6 \mathrm{~cm}$ of stone wool as an insulation system (right panel) leaves the historic wall significantly warmer than using $10 \mathrm{~cm}$ (left panel).

Although, on the one hand, we can see that the use of thicker insulation systems corresponds to lower heat losses, we expect to see higher moisture accumulation in the wall, as a result of this decrease of interstitial temperature. This issue was presented in the moisture accumulation analysis (Section 6.2.3). Figure 17 presents $\mathrm{RH}$ at the interface between the insulation system and the existing wall, recognized as the most critical part of the section [51]. As a general comment, alike for the base case simulation, $\mathrm{RH}$ remained below $95 \%$ for all the cases.

The comparison with the first and the second scenarios of thickness reduction $(6-8 \mathrm{~cm})$ has shown a very small difference in $\mathrm{RH}$, in a total range of $1 \%$.

Contrariwise, in the third scenario, it resulted that improving the vapour resistance of the internal finishing with the use of the two gypsum boards, instead of one, may contribute to reduce moisture accumulation during the wetting period more efficiently than reducing the insulation thickness (Figure 17, first period).

Anyway, it is important to mention that, while the third scenario avoids reducing insulation thickness with consequent minor thermal losses, on the other hand, this design choice is responsible for a delay during the drying phase (Figure 17, second period). However, during the drying phase, moisture content significantly dries out from the interstitial area in all the studied cases. This phenomenon was also already visible in Figures 13 and 14 for the base case scenario.

\section{Conclusions}

The study presents an applied research of the hygrothermal behaviour of an internal insulated historic brick wall, assessed at the most critical point of the stratigraphy, both by in situ measurements and predicted performance through dynamic simulations. 
The solution implemented for in situ monitoring balanced both thermal insulation improvement and the effects of the application over the historic wall: double stone wool boards $(100 \mathrm{~mm}$ in total), supported by own steel frame, punctually fixed to the historic wall, finished with a single gypsum board.

The analysed monitored period lasted three months, during winter period 2019-2020. In situ data were also used for validating the 2D simulation model.

Under the current conditions-climate data and studied stratigraphy, the results of both in situ monitoring and simulation prediction, evidenced no risk of frost damage of the brick wall. With regards to the risk of interstitial condensation, the simulation showed no risk either. In situ data analysis suggested nonetheless a more cautious interpretation. Though the highest values remained below $95 \%$, the condensation risk threshold, these data are dependent on sensors accuracy, which means that in fact the "true" RH could be over 95\%. Furthermore, more severe climate could result in crossing the risk threshold. Nonetheless, it is worth highlighting that given the simulation results, during the drying phase moisture content significantly dries out from the interstitial area.

Authors also proposed the exploitation of three other simulation scenarios and outputs, namely: reducing the insulation thickness $(6$ and $8 \mathrm{~cm})$ and decreasing the ingress of moisture into the wall by adding a second gypsum board layer to the initial $10 \mathrm{~cm}$ insulation technology (instead of the traditional vapour barrier).

It was found that reducing the thickness of the insulation material (by $2 \mathrm{~cm}$ or $4 \mathrm{~cm}$ ) decreased the moisture content in the wall, but not very significantly. More meaningful, instead, was the result obtained for the same insulation technology $(10 \mathrm{~cm}$ thickness) with two gypsum boards. In this case, the only verified drawback is the delay of the drying phase, absolutely compensated by the reduction of moisture accumulation during the wetting period.

The outcomes of this study are significant, not only to the scientific community, but mostly to practitioners, often missing guidance in energy refurbishment intervention of historic buildings. In other words, the thermal benefits of stone wool insulation with a certain thickness should not be compromised by the "fear" of moisture increase (once reducing it would not make much change). Instead, moisture accumulation might be improved—or better controlled—-through the addition of a second gypsum board.

Author Contributions: Authors are listed in alphabetical order. Conceptualization, M.C., P.D., L.D.P. and E.L.; Methodology, M.C., L.D.P. and E.L.; Validation: M.A., D.B.-L., M.C. and L.D.P.; Formal analysis, M.A., D.B.-L. and L.D.P.; Investigation: M.A., M.C., P.D., L.D.P. and E.L.; Simulation: D.B.-L. and A.T.; Data curation: M.A.; Writing—original draft preparation, L.D.P; Writing—review and editing,: M.A., D.B.-L., M.C., P.D., L.D.P., E.L. and A.T.; Visualization: D.B.-L., M.C. and L.D.P.; Supervision P.D. and A.T.; Project administration: P.D. and L.D.P. All authors have read and agreed to the published version of the manuscript.

Funding: The results presented in this paper are part of the HeLLo project that has received funding from the European Union's Horizon 2020 research and innovation programme under the Marie Sklodowska-Curie grant agreement No. 796712.

Acknowledgments: The authors acknowledge ROCKWOOL ${ }^{\circledR}$ Italia S.p.A. for the material and the support to the project. They also acknowledge Giorgi Roberto and Lavorazione Legno for the execution of the metering box. Finally, authors thank the University of Ferrara for providing the access and usage of Palazzo Tassoni Estense as the case-study.

Conflicts of Interest: The authors declare no conflict of interest. The funders had no role in the design of the study; in the collection, analyses, or interpretation of data; in the writing of the manuscript, or in the decision to publish the results.

\section{References and Note}

1. European Commission, EU Research. Cultural Heritage; European Commission: Brussels, Belgium, 2013. [CrossRef]

2. Akande, O.K.; Odeleye, D.; Coday, A. Energy Efficiency For Sustainable Reuse Of Public Heritage Buildings: The Case For Research. Int. J. Sustain. Dev. Plan. 2014, 9, 237-250. [CrossRef] 
3. European Commission. Commission Staff Working Document-European Framework for Action on Cultural Heritage, Brussels. 2018. Available online: https://ec.europa.eu/culture/library/commission-swd-europeanframework-action-cultural-heritage_en (accessed on 6 January 2020).

4. Phoenix, T. Lessons learned: ASHRAE's approach in the refurbishment of historic and existing buildings. Energy Build. 2015, 95, 13-14. [CrossRef]

5. Vereecken, E.; Van Gelder, L.; Janssen, H.; Roels, S. Interior insulation for wall retrofitting-A probabilistic analysis of energy savings and hygrothermal risks. Energy Build. 2015, 89, 231-244. [CrossRef]

6. Calzolari, M.; Davoli, P.; Pereira, L.D. Analysis of the risks related to the energy retrofit interventions of historic buildings. Recuper. Conserv. 2019, 154, 88-95. (In Italian)

7. Galatioto, A.; Ciulla, G.; Ricciu, R. An overview of energy retrofit actions feasibility on Italian historical buildings. Energy 2017, 137, 991-1000. [CrossRef]

8. Güleroğlu, S.K.; Karagüler, M.E.; Kahraman, İ.; Umdu, E.S. Methodological approach for performance assessment of historical buildings based on seismic, energy and cost performance: A Mediterranean case. J. Build. Eng. 2020, 31, 101372. [CrossRef]

9. Akkurt, G.G.; Aste, N.; Borderon, J.; Buda, A.; Calzolari, M.; Chung, D.; Costanzo, V.; Del Pero, C.; Evola, G.; Huerto-Cardenas, H.E.; et al. Dynamic thermal and hygrometric simulation of historical buildings: Critical factors and possible solutions. Renew. Sustain. Energy Rev. 2020, 118. [CrossRef]

10. Asdrubali, F.; Baldinelli, G. Thermal transmittance measurements with the hot box method: Calibration, experimental procedures, and uncertainty analyses of three different approaches. Energy Build. 2011, 43, 1618-1626. [CrossRef]

11. Wakili, K.G.; Tanner, C. U-value of a dried wall made of perforated porous clay bricks Hot box measurement versus numerical analysis. Energy Build. 2003, 35, 675-680. [CrossRef]

12. Soares, N.; Martins, C.; Gonçalves, M.; Santos, P.; da Silva, L.S.; Costa, J.J. Laboratory and in-situ non-destructive methods to evaluate the thermal transmittance and behaviour of walls, windows, and construction elements with innovative materials: A review. Energy Build. 2019, 182, 88-110. [CrossRef]

13. Bienvenido-Huertas, D.; Moyano, J.; Marín, D.; Fresco-Contreras, R. Review of in situ methods for assessing the thermal transmittance of walls. Renew. Sustain. Energy Rev. 2019, 102, 356-371. [CrossRef]

14. 3ENCULT. 3ENCULT Efficient Energy for EU Cultural Heritage (n.d.). Available online: http://www.3encult. eu/en/project/welcome/default.html (accessed on 19 June 2016).

15. Co2olBricks. Co2olBricks-Climate Change, Cultural Heritage \& Energy Efficient Monuments (2013). Available online: http://www.co2olbricks.eu/ (accessed on 28 August 2019).

16. EFFESUS. EFFESUS-Energy Efficiency for EU Historic Districts' Sustainability (2013). Available online: https://www.effesus.eu/ (accessed on 6 January 2020).

17. Troi, A.; Zeno, B. Energy Efficiency Solutions for Historic Buildings: A Handbook; Birkhäuser: Berlin, Germany; Basel, Switzerland, 2014. [CrossRef]

18. Zagorskas, J.; Kazimieras, E.; Turskis, Z.; Burinskien, M. Thermal insulation alternatives of historic brick buildings in Baltic Sea Region. Energy Build. 2014, 78, 35-42. [CrossRef]

19. Lucchi, E.; Becherini, F.; Concetta, M.; Tuccio, D.; Troi, A.; Frick, J.; Roberti, F.; Hermann, C.; Fairnington, I.; Mezzasalma, G.; et al. Thermal performance evaluation and comfort assessment of advanced aerogel as blown-in insulation for historic buildings. Build. Environ. 2017, 122, 258-268. [CrossRef]

20. Lucchi, E.; Roberti, F.; Alexandra, T. Definition of an experimental procedure with the hot box method for the thermal performance evaluation of inhomogeneous walls. Energy Build. 2018, 179, 99-111. [CrossRef]

21. Roque, E.; Vicente, R.; Almeida, R.M.S.F.; da Silva, J.M.; Ferreira, A.V. Thermal characterisation of traditional wall solution of built heritage using the simple hot box-heat flow meter method: In situ measurements and numerical simulation. Appl. Therm. Eng. 2020, 169, 114935. [CrossRef]

22. Adhikari, R.S.; Lucchi, E.; Pracchi, V. Energy modelling of historic buildings: Applicability, problems and compared results. In Proceedings of the 3rd European Workshop on Cultural Heritage and Preservation, Bolzano, Italy, 15-17 September 2013; pp. 119-125.

23. Calzolari, M. Prestazione Energetica Delle Architetture Storiche: Sfide e Soluzioni. Analisi dei Metodi di Calcolo per la Definizione del Comportamento Energetico; Franco Angelli: Milano, Italy, 2016; ISBN 9788891740885.

24. Belpoliti, V.; Bizzarri, G.; Boarin, P.; Calzolari, M.; Davoli, P. A parametric method to assess the energy performance of historical urban settlements. Evaluation of the current energy performance and simulation of retrofit strategies for an Italian case study. J. Cult. Herit. 2018, 30, 155-167. [CrossRef] 
25. Webb, A.L. Energy retrofits in historic and traditional buildings: A review of problems and methods. Renew. Sustain. Energy Rev. 2017, 77, 748-759. [CrossRef]

26. Bienvenido-Huertas, D.; Rubio-Bellido, C.; Pérez-Ordóñez, J.L.; Oliveira, M.J. Automation and optimization of in-situ assessment of wall thermal transmittance using a Random Forest algorithm. Build. Environ. 2020, 168, 106479. [CrossRef]

27. Bellia, L.; Alfano, F.R.D.; Giordano, J.; Ianniello, E.; Riccio, G. Energy requalification of a historical building: A case study. Energy Build. 2015, 95, 184-189. [CrossRef]

28. Ficco, G.; Iannetta, F.; Ianniello, E.; Romana, F.; Dell, M. U-value in situ measurement for energy diagnosis of existing buildings. Energy Build. 2015, 104, 108-121. [CrossRef]

29. Dell'Isola, M.; D'Ambrosio Alfano, F.R.; Giovinco, G.; Ianniello, E. Experimental analysis of thermal conductivity for building materials depending on moisture content. Int. J. Thermophys. 2012, 33, 1674-1685. [CrossRef]

30. Litti, G.; Khoshdel, S.; Audenaert, A.; Braet, J. Hygrothermal performance evaluation of traditional brick masonry in historic buildings. Energy Build. 2015, 105, 393-411. [CrossRef]

31. Kloseiko, P.; Arumagi, E.; Kalamees, T. Hygrothermal performance of internally insulated brick wall in cold climate: A case study in a historical school building. J. Build. Phys. 2015, 38, 444-464. [CrossRef]

32. Hansen, T.K.; Bjarløv, S.P.; Peuhkuri, R.H.; Harrestrup, M. Long term in situ measurements of hygrothermal conditions at critical points in four cases of internally insulated historic solid masonry walls. Energy Build. 2018, 172, 235-248. [CrossRef]

33. HeLLo. EU H2020 MSCA-IF-ES HeLLo Project (2019). Available online: https://cordis.europa.eu/project/rcn/ 215475/factsheet/en (accessed on 7 April 2019).

34. Sontag, L.; Nicolai, A.; Vogelsang, S. Validierung der Solverimplementierung des Hygrothermischen Simulationsprogramms Delphin; Technical report; Technische Universität Dresden: Dresden, Germany, 2013.

35. UNESCO. Ferrara, City of the Renaissance, and its Po Delta (1995). Available online: http://whc.unesco.org/ en/list/733 (accessed on 9 January 2019).

36. Davoli, P. Complexity, information surplus and interdisciplinarity management. The Rehabilitation of Tassoni Estense Palace in Ferrara. In Conserving Architecture; Jain, K., Ed.; AADI CENTRE: Ahmedabad, India, 2017; pp. 124-145, ISBN 978-81-908528-2-1.

37. Calzolari, M.; Davoli, P.; Pereira, L.D. From the dynamic simulations assessment of the hygrothermal behavior of internal insulation systems for historic buildings towards the HeLLo project. Int. J. Environ. Sci. Dev. 2020, 11, 278-285. [CrossRef]

38. Andreotti, M.; Calzolari, M.; Davoli, P.; Pereira, L.D.; Lucchi, E.; Malaguti, R. Design and construction of a new metering hot box for the in situ hygrothermal measurement in dynamic conditions of historic masonries. Energies 2020, 13, 2950. [CrossRef]

39. HeLLo. HeLLo Team Has Set-Up the Technical Worktables! 2019. Available online: https://hellomscaproject. eu/hello-team-has-set-up-the-technical-worktables/ (accessed on 15 January 2020).

40. STBA-Sustainable Traditional Buildings Alliance. Responsible Retrofit Guidance Wheel. Available online: http://responsible-retrofit.org/greenwheel/en (accessed on 6 January 2020).

41. English Heritage, Energy Efficiency and Historic Buildings: Application of part L of the Building Regulations to historic and traditionally constructed buildings. Energy Effic. Hist. Build. 2010, 1-72.

42. International Organization for Standardization (ISO). Ergonomics of the Thermal Environment-Analytical Determination and Interpretation of Thermal Comfort Using Calculation of the PMV and PPD Indices and Local Thermal Comfort Criteria; ISO 7730:2005; ISO: Geneva, Switzerland, 2005.

43. Ente Italiano di Normazione (UNI). Prestazione Igrotermica dei Componenti e Degli Elementi per Edilizia-Temperatura Superficiale Interna per Evitare L'umidita' Superficiale Critica e la Condensazione Interstiziale-Metodi di Calcolo; UNI EN ISO 13788; UNI: Milano, Italy, 2013.

44. International Organization for Standardization (ISO). Energy Performance of Buildings-Indoor Environmental Quality-Part 1: Indoor Environmental Input Parameters for the Design and Assessment of Energy Performance of Buildings; ISO 17772-1:2017; ISO: Geneva, Switzerland, 2017.

45. Lucchi, E.; Dias Pereira, L.; Andreotti, M.; Malaguti, R.; Cennamo, D.; Calzolari, M.; Frighi, V. Development of a Compatible, Low Cost and High Accurate Conservation Remote Sensing Technology for the Hygrothermal Assessment of Historic Walls. Electronics 2019, 8, 643. [CrossRef] 
46. Ente Italiano di Normazione (UNI). Prestazione Termoigrometrica dei Componenti e Degli Elementi di Edificio-Valutazione del Trasferimento di Umidità Mediante una Simulazione Numerica; UNI EN 15026; UNI: Milano, Italy, 2008.

47. WTA 6.2 Leaflet-Simulation of Heat and Moisture Transfer; WTA Publications: München, Germany, 2014; Volume 30.

48. TU Dresden, Institut fur Bauklimatik. Delphin 6.0.20. Material Database.

49. Fraunhofer IBP (Fraunhofer Institute for Building Physics). WUFI Pro-6.2 [Computer Software]; Fraunhofer IBP: Stuttgart, Germany, 2014.

50. WTA 6.5 Leaflet-Interior Insulation; WTA Publications: München, Germany, 2014.

51. Häupl, P.; Grunewald, J.; Fechner, H.; Stopp, H. Coupled heat air and moisture transfer in building structures. Int. J. Heat Mass. Transf. 1997, 40. [CrossRef]

52. Energieeinsparverordnung (EnEV). Verordnung über Energiesparenden Warmeschutz und Energiesparende Anlagentechnik bei Gebauden. Bundesgesetzblatt. 2007. Available online: https://www.enev-profi.de/wpcontent/uploads/EnEV-2014-Lesefassung.pdf (accessed on 6 January 2020).

(C) 2020 by the authors. Licensee MDPI, Basel, Switzerland. This article is an open access article distributed under the terms and conditions of the Creative Commons Attribution (CC BY) license (http://creativecommons.org/licenses/by/4.0/). 